\title{
Simulation and optimization of a hybrid unglazed solar photovoltaic-thermal collector and heat pump system with two storage tanks
}

\author{
Dannemand, Mark; Sifnaios, loannis; Tian, Zhiyong; Furbo, Simon
}

Published in:

Energy Conversion and Management

Link to article, DOI:

10.1016/j.enconman.2019.112429

Publication date:

2020

Document Version

Peer reviewed version

Link back to DTU Orbit

Citation (APA):

Dannemand, M., Sifnaios, I., Tian, Z., \& Furbo, S. (2020). Simulation and optimization of a hybrid unglazed solar photovoltaic-thermal collector and heat pump system with two storage tanks. Energy Conversion and Management, 206, [112429]. https://doi.org/10.1016/j.enconman.2019.112429

\section{General rights}

Copyright and moral rights for the publications made accessible in the public portal are retained by the authors and/or other copyright owners and it is a condition of accessing publications that users recognise and abide by the legal requirements associated with these rights.

- Users may download and print one copy of any publication from the public portal for the purpose of private study or research.

- You may not further distribute the material or use it for any profit-making activity or commercial gain

- You may freely distribute the URL identifying the publication in the public portal 
Elsevier Editorial System(tm) for Energy Conversion and Management or its open access mirror Manuscript Draft

Manuscript Number: ECM-D-19-07045R2

Title: Simulation and optimization of a hybrid unglazed solar photovoltaic-thermal collector and heat pump system with two storage tanks

Article Type: Original research paper

Section/Category: 1. Energy Conservation and Efficient Utilization

Keywords: Solar-assisted heat pump; TRNSYS; buffer tank; domestic hot water tank; photovoltaic-thermal collector; heat storage.

Corresponding Author: Dr. Zhiyong Tian, Ph.D

Corresponding Author's Institution: Norwegian University of Science and Technology

First Author: Mark Dannemand, PhD

Order of Authors: Mark Dannemand, PhD; Ioannis Sifnaios; Zhiyong Tian, Ph.D; Simon Furbo, PhD

Abstract: Solar thermal energy systems combined with heat pumps are becoming popular solutions for covering space heating and domestic hot water demand in European Union households. There is a great potential for developing high performing systems by combining components in systems in new ways. This study focuses on the performance of a system consisting of heat pump, photovoltaic-thermal solar collector and two storage tanks. This system is proposed to potentially have better performance compared to air-to-liquid heat pump system while being less costly compared to a liquid-to-liquid heat pump system with ground sourced heat exchanger. The system was set up at the Technical University of Denmark in 2017, for providing domestic hot water. A simulation model of the system was created in the transient simulation software and the data from the experiment were used for its validation. The modulating heat pump was modelled via a function applied to the scale factor and the thermal mass of the heat pump was taken into account be including additional pipes around the heat pump. The performance of the system was assessed using selected key performance indicators. A parametric analysis was performed identifying component sizes that improved the system's performance. The improved system produced 55\% more electricity, had 23\% lower electric consumption and wasted 11\% less heat by minimizing heat losses compared to the demonstration system. The improved system had a solar thermal fraction of 0.58, a solar electrical fraction of 1.51 and a renewable energy fraction of 0.75 . The system was however oversized compared to the load applied to the system as it was built to cover only a domestic hot water demand. For the system to be economically attractive it must cover a larger load. 


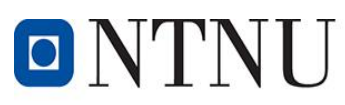

Norwegian University of

Science and Technology

\section{Cover letter}

\section{Dear Editors:}

We would like to submit the revised manuscript entitled "Simulation and optimization of a hybrid unglazed solar photovoltaic-thermal collector and heat pump system with two storage tanks" for the consideration for publication in the journal of Energy Conversion and Management.

The abbreviations and acronyms in title, abstract, headings and highlights have been avoided. We have double-checked this. Thanks.

Thanks a lot for your patience to read this letter. If any further question, please do not hesitate to contact us. Correspondence has been addressed to Zhiyong Tian at the following address, phone and email address below.

Best regards

\section{Zhiyong Tian}

Address: Byggteknisk, 2-239, Gløshaugen, Høgskoleringen 7A, Trondheim,7034, Norway

Phone: 0045-52781629

Email: zhiyong.tian@ntnu.no, tianzy0913@163.com 
Highlights:

- Solar assisted heat pump system with buffer tank as source for heat pump

- Uncovered photovoltaic-thermal collector used to charge buffer tank in periods without irradiance

- Transient simulation model validated with experimental measurements

- Yearly performance of system including parameter variation

- Modulating heat pump with thermal mass modelled via scale factor and extra pipes 


\title{
Simulation and optimization of a hybrid unglazed solar photovoltaic-thermal collector and heat pump system with two storage tanks
}

\author{
Mark Dannemand ${ }^{1}$, loannis Sifnaios ${ }^{1}$, Zhiyong Tian $^{2,1^{*}}$, Simon Furbo $^{1}$ \\ 1 DTU Civil Engineering, Technical University of Denmark, Brovej, Building 118, DK-2800, Kgs. Lyngby, \\ Denmark
}

2 Department of Civil and Environmental Engineering, Norwegian University of Science and Technology, Trondheim, Norway

Corresponding author: markd@byg.dtu.dk (Mark Dannemand), zhiyong.tian@ntnu.no (Zhiyong Tian), tianzy0913@163.com(Zhiyong Tian).

\begin{abstract}
Solar thermal energy systems combined with heat pumps are becoming popular solutions for covering space heating and domestic hot water demand in European Union households. There is a great potential for developing high performing systems by combining components in systems in new ways. This study focuses on the performance of a system consisting of heat pump, photovoltaicthermal solar collector and two storage tanks. This system is proposed to potentially have better performance compared to air-to-liquid heat pump system while being less costly compared to a liquid-to-liquid heat pump system with ground sourced heat exchanger. The system was set up at the Technical University of Denmark in 2017, for providing domestic hot water. A simulation model of the system was created in the transient simulation software and the data from the experiment were used for its validation. The modulating heat pump was modelled via a function applied to the scale factor and the thermal mass of the heat pump was taken into account be including additional pipes around the heat pump. The performance of the system was assessed using selected key performance indicators. A parametric analysis was performed identifying component sizes that improved the system's performance. The improved system produced $55 \%$ more electricity, had $23 \%$ lower electric consumption and wasted $11 \%$ less heat by minimizing heat losses compared to the demonstration system. The improved system had a solar thermal fraction of 0.58 , a solar electrical fraction of 1.51 and a renewable energy fraction of 0.75 . The system was however oversized compared to the load applied to the system as it was built to cover only a domestic hot water demand. For the system to be economically attractive it must cover a larger load.
\end{abstract}

Keywords: Solar-assisted heat pump, TRNSYS, buffer tank, domestic hot water tank, photovoltaicthermal collector, heat storage

\section{Nomenclature}

$\mathrm{Q}_{\mathrm{PVT}} \quad$ Thermal energy produced by the photovoltaic-thermal collector [kWh]

$\mathrm{Q}_{\mathrm{HS}} \quad$ Thermal energy produced by the heating system (tapped energy) [kWh] 
Thermal energy supplied to the domestic hot water tank and heat pump [kWh] Thermal energy supplied to the primary (source) side of the heat pump [kWh]

$\mathrm{Q}_{\text {sup,HS }}$

$\mathrm{Q}_{\text {primary,HP }}$

$Q_{\text {PVT,DHW }}$

[kWh]

$\mathrm{E}_{\mathrm{PVT}}$

$E_{H S}$

$f_{\text {sol,th }}$

$f_{\text {sol,el }}$

$f_{\text {ren }}$

$f_{\text {ISPF }}$ Thermal energy supplied by the photovoltaic-thermal collector to the DHW tank

Electrical energy produced by the photovoltaic-thermal collector [kWh]

Electrical energy consumed by the heating system [kWh]

Solar thermal fraction [-]

Solar electrical fraction [-]

Net renewable energy factor [-]

Inverse system seasonal performance factor [-]

\section{Abbreviations}

DHW Domestic Hot Water

PVT Photovoltaic-Thermal

ISPF Inverse Seasonal Performance Factor

HS Heating system, referring to the heat pump and domestic hot water tank

SAHP Solar Assisted Heat Pump

KPI Key Performance Indicator

WISC Wind and Infrared Sensitive Collector

COP coefficient of performance

\section{Introduction}

Space heating and hot water consumption accounts for $79 \%$ of the total final energy use in EU households. In 2018, approximately $84 \%$ of heating and cooling was generated from fossil fuels while only $16 \%$ is generated from renewable sources [1]. In order to fulfil EU's climate and energy goals, the heating and cooling sector must reduce its energy consumption and cut its use of fossil fuels significantly [1]. Solar thermal energy systems combined with heat pumps have become more and more popular options in order to increase the renewable energy share for space heating and domestic hot water systems [2]. Currently, products for combining solar thermal collectors and photovoltaic (PV) panels into one hybrid photovoltaic-thermal (PVT) collector are being developed across the industry. Utilizing PVT collectors allows potentially for developing more efficient solar heating systems when the PVT collectors are combined with heat pumps and storage tanks.

\subsection{Literature study}

The International Energy Agency (IEA) Solar Heating and Cooling Programme (SHC) Task 44/ Heat Pump Programme (HPP) Annex 38 "Solar and heat pumps system" operated from 2010 to 2013. It focused on the assessment of performances and relevance of combined systems using solar thermal collectors and heat pumps, to provide common definition of performances of such systems and to contribute to successful market penetration of these new systems [3]. IEA-SHC Task 60 "Application of PVT Collectors and New Solutions in heating, ventilation and air-conditioning (HVAC) Systems" from January 2018 - December 2020 has been initialed to further develop PVT collectors in the application of HVAC systems [4]. 
Many research projects on solar assisted heat pump (SAHP) systems have been carried out. Bellos et al. [5] made an energetic and financial evaluation of SAHP systems, and found that the most economically attractive system design depended on the electricity price, concluding that, for high electricity prices, the SAHP system with PVT and a liquid based heat pump was the best solution. Rad et al. did a feasibility study of combined solar thermal and ground source heat pump systems [6]. It was found that the net present value of the proposed hybrid system based on the 20-year life-cycle cost analysis was estimated to be in a range of 3.7\%-7.6\% (or $\$ 1500$ to $\$ 3430$ Canadian dollar) lower than the conventional ground sourced heat pump (GSHP)system depending on the drilling cost. Buonomano et al. [7] assessed the energy and economic performance of a Building Integrated flatplate Photovoltaic Thermal (BIPVT) system for a residential application. The case study showed that the payback period varied from 11 years for South European weather zones to 20 years for North European zones. Fine et al. [8] did a detailed model of a PVT domestic hot water (DHW) system with a cascade heat pump and one storage tank. They found that the system with the cascade heat pump performed better than a PVT heat pump system with a single heat pump or a system with evacuated tube collectors for selected climates in USA and Canada. Busato et al. did a study on which source for the heat pump was the most favorable including ground source heat exchanger and solar collectors [9]. The analysis revealed that the most energy efficient solution both for absorption and compression heat pump based systems was to adopt a multi-source system. Lämmle et al. [10] evaluated the performance of different PVT collector types in four different heating systems using the transient system simulation tool (TRNSYS). They concluded that unglazed PVT collectors achieve high electrical yields, and glazed PVT collector with low-e coatings achieve high thermal yields. Zarrella et al. [11] validated a TRNSYS type based on a novel lumped parameter model for photovoltaic thermal hybrid solar collectors. The contribution of the thermal capacitances of the materials and the heat-carrier fluid of the collector were considered in the type. Calise et al. [12] carried out thermo-economic optimization of a solar-assisted heat pump based on transient simulations and computer design of experiments. A simple pay-back period of about 5 year was achieved based on a case study. Emmi et al. [13] presented a case study on a heat pump coupled with photovoltaic thermal hybrid solar collectors. The solar-air sources system was the best solution for the case study. Jouhara et al. [14] investigated the performance of a combined heat pump solar PVT system and its potential in district heating applications. Solar fraction from $60 \%$ to $100 \%$ was achieved in different days depending on the solar radiation. Dupeyrat et al. [15] studied the thermal and electrical performances of PVT solar hot water systems. They confirmed that PVT collectors in the building envelop can be more advantageous than standard PV and solar thermal components considering the exergy and the primary energy saving. Gürlich et al. [16] investigated the performance of photovoltaic-thermal hybrid collectors for direct regeneration in a European building retrofit case study. They showed that PVT collectors used for heat (primary DHW) and electricity offer approximately 6-7\% higher exergetic efficiency than thermal and PV collectors equally sharing the available surface area. Chen et al. [17] did the performance analysis and multi-objective optimization of a hybrid PVT collector for domestic hot water application. The optimal value of tank volume on Pareto frontier showed an equally scattering distribution between $99.5 \mathrm{~L}$ and $218.6 \mathrm{~L}$ for a $2 \mathrm{~m}^{2}$ glazed PVT collector. Li et al. [18] carried out experimental performance analysis on a directexpansion solar-assisted heat pump water heater. They found that the small system with lower capital cost and smaller collector/evaporator area has the advantage to integrate it with building roof. Deng et al. [19] did the simulation and optimization study on a solar space heating system combined with a low temperature heat pump for single family rural residential houses in Beijing. It is further found that the equivalent solar heat price per kWh was too high under the current solar market cost price and collector technology. 
Sakellariou et al. [20] conducted a sensitivity analyses on a PVT based solar assisted ground source heat pump system using TRNSYS simulation software. It was found that the storage capacity and the plate heat exchanger's effectiveness, contribute the most to the system's and heat productivity of PVT. Aldubyan et al. [21] reported the evaluation of the short and long-term electrical performance of a unglazed PVT system coupled with borehole thermal energy storage in two extreme climate zones in the United States. Significant improvements in PVT cell efficiency in the system without a ground-coupled heat pump compared with conventional PV panels was found. Jonas et al. [22] did a simulation study using TRNSYS of a SAHP system with a borehole ground storage and compared it to other types of systems. They showed that the seasonal performance factor of parallel solar thermal and ground source heat pump systems was between 0.5-1.1 (Strasbourg) and 1.0-2.0 (Helsinki) higher than the seasonal performance factor of parallel solar thermal and air source heat pump systems with the same solar collector area. Li et al. [23] also used TRNSYS to study a SAHP system. It was concluded that the properly designed solar thermal heat pump heating system can operate effectively and reduce tremendous energy consumption compared with the traditional heating system used in cold climate buildings. Xi et al. [24] introduced in their study a ground coupled SAHP system for space heating and DHW. They optimized the system design with TRNSYS and presented its performance for operating in Beijing. Chen and Yang [25] presented a TRNSYS simulation of a SAHP system with ground coupled heat exchanger to find an optimal design for the north China area. The annual total heat extraction plus $75 \%$ of the hot water requirement could be provided by solar energy in the optimized design. Poppi et al. [26] studied different SAHP combined systems, and found that the type and size of the heat pump had a large impact on the electricity consumption required to cover the heat demands of the selected cases. In another study, Poppi et al. [27] analyzed the economic impact of changing the components in SAHP systems, and found that the optimal solution depended on the boundary conditions such as heat demands, climatic conditions and electricity price. Sterling and Collins [28] performed a feasibility analysis of different SAHP systems and used TRNSYS for assessing their performances. It was found that the electrical consumption and operating cost were the lowest with indirect-style solar assisted heat pump. Tzivanidis et al. [29] made an energetic and financial evaluation of a SAHP system comparing it to two other heating systems focusing on the climate of Athens, Greece. They found that the SAHP system had the best energetic performance but not the lowest net present value with the stated electricity prices. Girard et al. [30] showed that the COP of the ground source heat pump system was increased by adding solar collectors. The payback periods of solar-assisted ground-source heatpumps are between 8.5 and 23 years depending on location. Kjellsson et al. [31] did a TRNSYS simulation on solar collectors and ground-source heat pumps in Sweden. They reported that COP values obtained during periods with favorable operational conditions was misleading if the overall annual system performance (SPF) was not mentioned in the same context. Pärisch et al. [32] did investigations and model validation of a ground-coupled heat pump for the combination with solar collectors. It was shown that rising source temperatures did only significantly increase the coefficient of performance (COP), if the source temperature was below $10-20^{\circ} \mathrm{C}$, depending on the temperature lift between source and sink. Razavi et al. [33] designed a solar assisted GSHP system to provide heating load and domestic hot water for a house located in Zahedan, Iran. Energy consumption of solar assisted GSHP system was $8.7 \%$ lower than GSHP standalone system Rada et al. [34] did energy assessment of solar technologies coupled with a ground source heat pump system for residential energy supply in Southern European climates. They found that PV and solar thermal systems allowed high energy savings compared in Italy. Si et al. [35] compared the performance of two different solar-ground source heat pump systems. It was suggested to operate the system without heat pump in transition seasons. Wang et al. [36] also studied the performance of a hybrid 
ground source SAHP system . They reported that the control strategy of load circulation pump could result in energy saving.

\subsection{Scope}

This study focuses on the performance of a system consisting of a heat pump, a PVT collector and two storage tanks. An experimental setup with an unglazed PVT collector, liquid-to-liquid heat pump, a domestic hot water (DHW) tank and a buffer tank has been set up at the Technical University of Denmark in 2017. The load for the system was automated hot water tapping. The thermal output of the unglazed PVT collector was used to charge both tanks on sunny days. Also, the unglazed PVT collector was used as a heat exchanger, to extract low temperature heat from the ambient environment when there was limited or no solar radiation available. This was used to increase the water temperature in the buffer tanks which was the source of the heat pump. This type of system not only potentially allows for having better performing systems compared to air-toliquid heat pump systems, but also has lower cost compared to liquid-to-liquid heat pump systems with a ground sourced heat exchanger. The performance of the demonstration system has been analyzed by Dannemand et al. [37]. In the present study, a TRNSYS model was built and validated with the measurements and the yearly performance of the system was simulated. Furthermore, the sizing of various components was varied in a parametric study. It was found that improvements on the demonstration system were possible, in order to enhance its performance.

To the best of the authors' knowledge, only limited publications on systems consisting of heat pump, PVT collector and two storage tanks have been made. No studies were found on modeling and validation of such systems using TRNSYS in the literature.

\section{Methods}

In this section the system setup under investigation is described, as well as the TRNSYS model created for simulating its operation. Lastly, the Key Performance Indicators (KPI) used for assessing the system performance are presented.

\subsection{Experimental set up}

The PVT assisted heat pump system consisted of at $3.1 \mathrm{~m}^{2}$ uninsulated uncovered, wind and infrared sensitive collector (WISC) prototype PVT collector manufactured by Racell Technologies. Monocrystalline solar cells covered $2.58 \mathrm{~m}^{2}$ of the absorber area. The PVT collector was installed with a $45^{\circ}$ tilt facing south, raised approximately $10 \mathrm{~cm}$ above roof, allowing air to pass freely on the backside. The thermal absorber of PVT collector was connected to a heat exchanger spiral in the bottom of a 160 liters domestic hot water (DHW) storage tank. Further, the solar collector loop was connected to a 200 liters buffer storage tank with a direct inlet to the top of the tank. A $40 \%$ propylene glycol/water mixture was used to fill the solar collector loop and buffer storage.

The DHW tank was also heated by a heat pump, via a heat exchanger spiral in the top of the tank. When heat from the solar collector was insufficient to maintain the required temperature level in the top of the DHW tank, the heat pump was activated. The heat pump used was a NIBE F1155-6, with a frequency speed regulated compressor. The supplier specified thermal power output at $0 / 35$ 
${ }^{\circ} \mathrm{C}\left(0{ }^{\circ} \mathrm{C}\right.$ at the inlet on the source side of the heat pump, $35^{\circ} \mathrm{C}$ at the outlet on the load side of the heat pump) was $3.15 \mathrm{~kW}$ (thermal) with an electrical power consumption of $0.67 \mathrm{~kW}$ (electrical) at $50 \mathrm{~Hz}$. The source side of the heat pump was connected to the buffer storage tank.

The pipes between the heat pump and the DHW and buffer storage tanks were each approximately 6 meters long. The pipes between the DHW tank and the PVT panel were each 24 meters long and approximately half the pipe was located indoors and half outdoors. In order to investigate the performance of the system, tapping of domestic hot water from the DHW tank occurred three times per day with an energy draw off of $4.5 \mathrm{kWh}$ per day. That corresponded to 110-145 liters of water per day, depending on the temperature difference between the cold and hot water. The tapping was realized via an automated system at the test facilities. Figure 1 shows a schematic of the system under investigation.

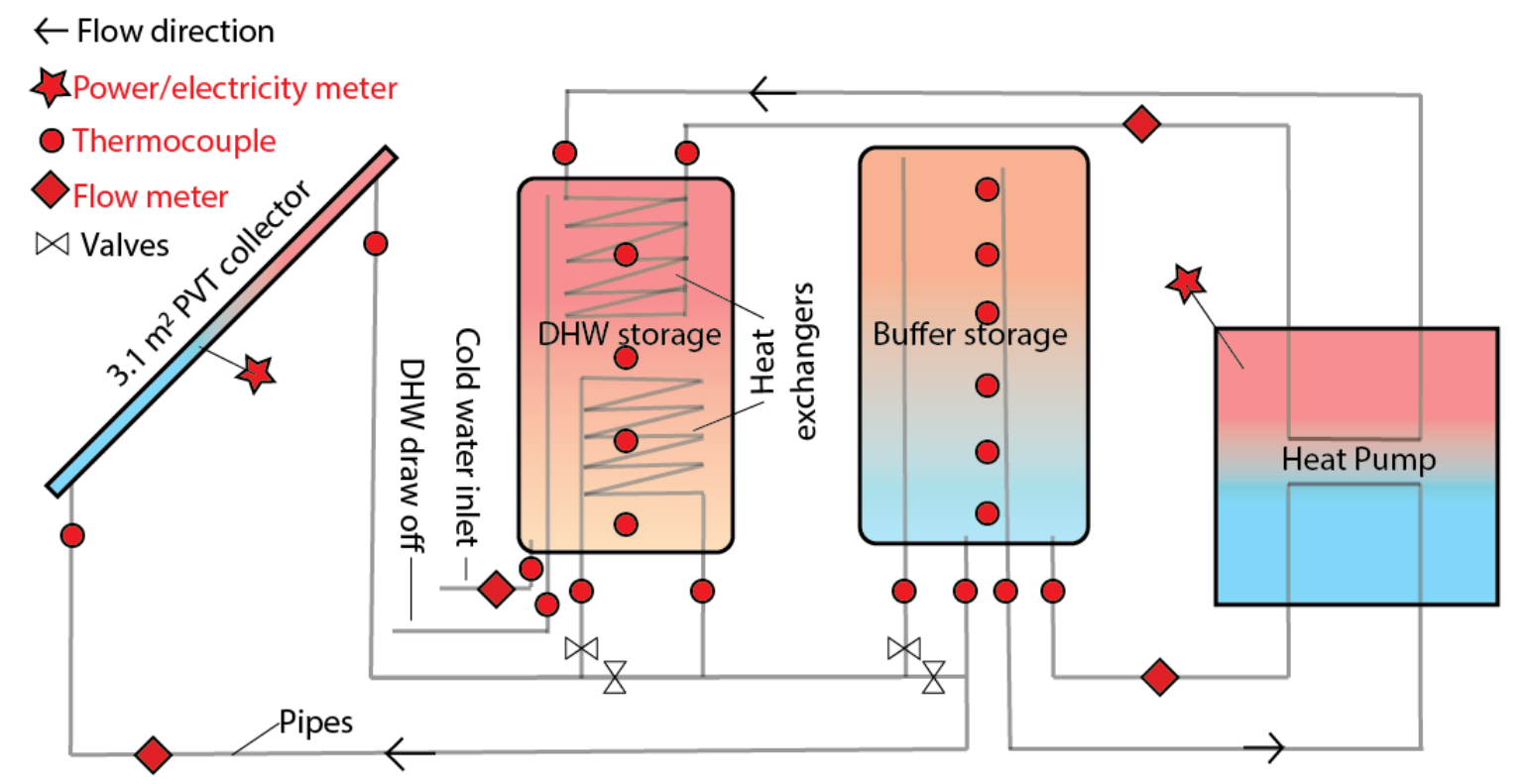

Figure 1: Schematic of the investigated PVT system at the Technical University of Denmark with measurement locations

\subsubsection{Measurements}

Temperatures, flow rates and electricity production/consumption were measured at the locations indicated in Figure 1. Measurements from August 7 to December 21, 2017 were used for validating the TRNSYS model.

A National Instrument cRIO with 9214 and 9403 cards were used for the data logging. Absolute temperatures of the fluid in the system were measured with thermocouples type $T$ (uncertainty less than $\pm 0.42{ }^{\circ} \mathrm{C}$ in the applied temperature range) at the locations indicated in Figure 1 . The ambient temperature was likewise measured with a thermocouple type T. A five junction thermopile (uncertainty less than $\pm 0.15^{\circ} \mathrm{C}$ ) were used to measure the temperature difference between the inlet and outlet of the PVT collector. Kamstrup and Brunata flow meters (class 2 sensor, accuracy less than $2 \%$ after calibration) were used to measure the flow rates in the loops indicated in Figure 1. CMP11 Kipp \& Zonen pyranometers (accuracy less than 2\%) were used to measure the total and diffuse irradiances in the same plane as the collector. The infrared irradiation on the tilted collector were measured using a CG1 pyrgeometer from Kipp \& Zonen (accuracy less than $1 \%$ in the application range). Electronic single phase energy meters from Eltako Electronics (accuracy less than 
1\%) were used to measure the electricity consumption of the heat pump and the electricity production of the PVT collector. Typical calculated uncertainty of the measured heat output of PVT collector, which is based on measured temperature difference and flow rate, is within $5 \%$. Lastly, the wind speed in the collector plane was measured with an ultra-sonic wind speed and direction sensor from Gill (accuracy less than 2\%). It was noticed that the average wind speed in the collector plane was $31 \%$ of the wind speed measured at the DTU Climate Station [38]. Since this percentage was relatively constant, this factor was applied in the TRNSYS yearly simulation for finding the speed in the collector plane.

\subsubsection{Control strategy}

The control strategy applied to the experimental setup was as follows:

- When the temperature in the top of the DHW tank dropped below $42{ }^{\circ} \mathrm{C}$, the heat pump charged the DHW tank until the temperature in the top of the tank reached $50{ }^{\circ} \mathrm{C}$.

- When the temperature at the outlet of the PVT collector was $4{ }^{\circ} \mathrm{C}$ higher than the bottom of the buffer storage, the collector loop pump started. The solar collector loop pump stopped when the temperature difference dropped below $0{ }^{\circ} \mathrm{C}$.

- When the temperature in the top of the buffer tank was below $25^{\circ} \mathrm{C}$, the flow in the collector loop was directed into the top of the buffer storage tank. If the temperature in the top of the buffer tank was higher than $25^{\circ} \mathrm{C}$, the tank was bypassed because the maximum allowed inlet temperature to the source side of the heat pump was $30^{\circ} \mathrm{C}$.

- The flow in the collector loop was directed through the heat exchanger in the lower part of the DHW tank when the temperature at the outlet of the PVT collector was $4{ }^{\circ} \mathrm{C}$ higher than the bottom of the DHW tank. The DHW tank was bypassed when the temperature difference dropped below $0^{\circ} \mathrm{C}$.

The used control strategy in the demonstration installation, although simple and easy to implement, may not be optimal for the system. There were scenarios when the collector loop pump was in operation while both storage tanks were bypassed.

\subsection{Simulation model and validation}

The software selected for assessing the system performance was the simulation software TRNSYS, as it is a flexible graphically based software able to model transient systems, widely used by the energy simulation community.

\subsubsection{Part models}

Initially, models of the PVT collector, the heat pump and the tanks were created to validate the individual parts of the system, before they were combined to the full model of the PVT system.

\subsubsection{Photovoltaic-thermal collector model}

The prototype PVT collector had not been characterized in detail before the PVT system was set in operation. Therefore, a model only focusing on the collector was initially built in order to identify the collector's coefficients. TRNSYS "Type 203: PVT collector" developed by Institut für Solarenergieforschung GmbH (ISFH) [39] was chosen for the PVT collector. The thermal and electrical outputs of the model, calculated using the measured weather conditions, inlet temperatures and flows, were compared to the measured output of the PVT prototype. The collector parameters in the 
model were adjusted to give a good fit between measurements and calculations. This was done considering the characteristics of similar collectors, but also the installation, in order to have reasonable parameters for the PVT collector. The values listed in Table 1 were used for the parameters in the PVT collector model. The default values of Type 203 were used for parameters not listed in Table 1.

Table 1: Parameters in Type 203 used for the PVT collector model.

\begin{tabular}{llll}
\hline Parameter & Description & Value & Unit \\
\hline 8 & Conversion factor (thermal) & 0.66 & - \\
9 & Wind dependent conversion factor & 0.01 & $\mathrm{~s} / \mathrm{m}$ \\
10 & Heat loss coefficient & 16 & $\mathrm{~W} /\left(\mathrm{m}^{2} \cdot{ }^{\circ} \mathrm{C}\right)$ \\
11 & Wind dependent heat loss coefficient & 3.5 & $\mathrm{~J} /\left(\mathrm{m}^{3} \cdot{ }^{\circ} \mathrm{C}\right)$ \\
14 & Heat capacity & 20 & $\mathrm{~kJ} /\left(\mathrm{m}^{2} \cdot{ }^{\circ} \mathrm{C}\right)$ \\
23 & PVT module electrical efficiency at reference condition* & 0.098 & - \\
28 & Coefficient for temperature dependent electrical efficiency & -0.4 & $\% /{ }^{\circ} \mathrm{C}$ \\
\hline The relatively low electrical efficiency of the PV part of the PVT collector $(0.098)$ reflects that only \\
part (83\%) of the prototype PVT collector was covered with solar cells. Also the losses in the inverter \\
is included in this value as the electrical output from the PVT collector was measured after the \\
inverter.
\end{tabular}

\subsubsection{Heat pump model}

The heat pump operation including the pipe loops on the source and load side, was simulated in TRNSYS. The electrical power consumption, temperatures and thermal power in the pipe loops were used to calibrate the model in order to fit the measurements. TRNSYS "Type 927: Normalized waterto-water heat pump" was used for the heat pump and "Type 604: Bi-directional, node pipe with wall and insulation mass" was used for the $4 \times 6$ meter pipes between the heat pump and the two tanks in order to include the thermal mass and fluid in the pipes. A performance map from the heat pump supplier was used to calculate the performance of the heat pump.

From the conducted experiments, it was observed that the heat pump operated for very short periods throughout the day. For this reason, a significant amount of heat was lost to the ambient due to the thermal capacity of the heat pump. However, none of the existing TRNSYS heat pump components was able to take into account this effect. It was also noticed that, after the heat pump operation, heat was left in the pipes causing significant heat losses to the ambient. For these reasons, it was decided to include in the TRNSYS model additional $19 \mathrm{~m}$ of pipes to the load loop and $2 \mathrm{~m}$ to the source loop, to compensate for the heat pump thermal mass. Pipe insulation thickness and thermal conductivity were implemented considering the thermal bridges in the physical installation.

The physical heat pump used a frequency inverter in order to modulate the heat pump's compressor operation for optimal performance. The electrical power consumption of the heat pump varied throughout the measurement period, having higher electrical consumption for colder inlet temperatures on the source side of the heat pump. Modulating heat pump technology is currently not included in any of the standard TRNSYS heat pump components. For this reason, a function using the source temperature entering the heat pump was included in the heat pump model to control the 
heat pump's scale factor. This way, the thermal output and electrical consumption of the heat pump could be increased or decreased according to the source temperature, simulating the modulating power operation of the heat pump. In this way the electrical consumption of the heat pump varied with the operating conditions in a similar way as it did in the experimental setup. Lastly, in order to include the standby electricity consumption of the heat pump in TRNSYS, a constant $19 \mathrm{~W}$ were added to the heat pump electrical power consumption.

\subsubsection{Buffer and domestic hot water tank models}

Both buffer and DHW tanks were simulated with TRNSYS "Type 534: Vertically cylindrical storage tanks with optional immersed heat exchangers". Models focusing only on the temperature development inside the tanks in standby periods were used to adjust the heat loss coefficient and the downwards thermal conductivity in the tanks, so that the measurement and simulation results were in good agreement. The buffer tank had a volume of 200 liters and height of $1.4 \mathrm{~m}$ and the DHW tank had a volume of 160 liters and a height of $1.2 \mathrm{~m}$. The geometry and design of the tanks in the model were set to match the actual designs.

The measurements indicated some degree of thermosiphon in the loop between the buffer tank and the heat pump, in periods where there was no flow in the loop. The thermosiphon appeared to go the opposite direction of the normal flow in the loop. When the heat pump operation stopped, the temperature sensor at the inlet of the buffer tank from the heat pump (source side) located in a pipe approximately $40 \mathrm{~cm}$ below the tank, remained at a temperature level similar to the bottom of the buffer tank. This indicated that fluid flowed down from the tank through this pipe. On the contrary, the temperature sensor at the outlet of the tank (to the heat pump source), remained above the buffer tank and ambient air temperature suggesting that some heat was transferred via the pipes into the tank. This suggests that thermosiphon occurred after the heat pump stopped, indicating that leftover heat from the heat pump or heat from the standby crankcase heater was transferred to the upper part of the buffer tank. Without thermosiphon the temperature sensors of the inlet and outlet measured in the pipes close to the tank would have stabilized close to ambient indoor temperature. A miscellaneous heat gain to the upper part of the tank model and high heat loss coefficients were added to the buffer tank model to compensate for thermosiphon.

\subsubsection{Full model}

The settings for the part models of the individual components were combined into a full PVT system model. The system was built up using the components and types listed in Table 2. Figure 2 shows the main components in the TRNSYS environment.

Table 2: Components and types used in the TRNSYS model

\begin{tabular}{|c|c|c|}
\hline Component & Type number & Type name \\
\hline PVT collector & 203 & PVT collector \\
\hline Pipes & 604 & $\begin{array}{l}\text { Bi-directional node pipe with wall and insulation } \\
\text { mass }\end{array}$ \\
\hline Heat pump & 927 & Normalized water-to-water heat pump \\
\hline DHW / buffer storage tank & 534 & $\begin{array}{l}\text { Vertically cylindrical storage tanks with optional } \\
\text { immersed heat exchangers }\end{array}$ \\
\hline Controls & 911 & Differential controller with lockouts \\
\hline Load profile & 14 & Forcing function - general \\
\hline Flow diverter / T-piece & 11 & Flow diverter - other fluids \\
\hline
\end{tabular}


A DHW tapping pattern matching the pattern in the demonstration system was applied to the model. The measured cold water temperature was implemented and tap flow rate was adjusted to fit the measured tapped energy quantities to the simulated.

The control strategy applied for the physical system as described in section 2.1.2 Control strategy, was implemented in the TRNSYS model by four individual Type 911 controllers. The absorber temperature simulated by the Type 203 was used at the upper temperature limit for hysteresis control of the pump for the solar collector loop. The flow in the solar collector loop was set to 3 liters per minute.

The pipes in the solar collector loop were divided into indoor and outdoor parts and the insulation was implemented in the simulation model according to the actual dimensions and conditions.

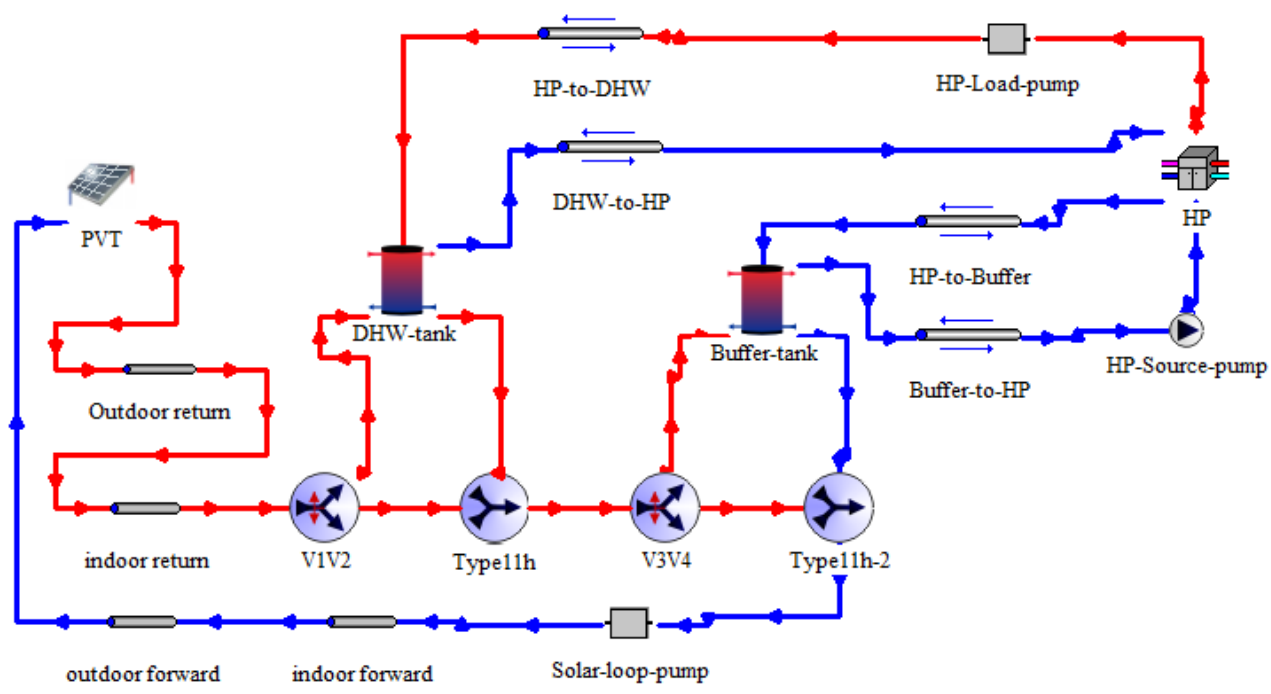

Figure 2: Main components of the PVT heat pump dual tank model in TRNSYS.

\subsubsection{Yearly simulation}

In order to evaluate the performance of the system throughout the year in Danish climatic conditions, a new simulation was performed using the validated TRNSYS model. The difference between the validated model and yearly simulation was that data from measurements were not fed to the model, but reference conditions were used instead. The system simulated supplied domestic hot water at $50{ }^{\circ} \mathrm{C}$ with a constant cold water temperature of $10{ }^{\circ} \mathrm{C}$, without supplying water for space heating. Since the system was assumed to be placed indoors, it was exposed to a constant ambient temperature throughout the year of $20{ }^{\circ} \mathrm{C}$. The tapping of domestic hot water occurred three times per day; namely at $7 \mathrm{am}, 12 \mathrm{pm}$ and $7 \mathrm{pm}$. The total daily need for domestic hot water was 100 liters, amount that corresponds to an average single family house in Denmark. Regarding weather data, the reference weather file available in TRNSYS from Meteonorm library named "DKKobenhavn-Taastrup-61800", was used for the simulation.

\subsubsection{Parameter variations}

Parameter variation for various components (PVT collector area, tank volumes) of the system were performed in order to identify their effect on the system's performance. Afterwards, some scenarios where the existing system was improved regarding insulation, pipe length and heat exchanger dimensions were investigated. Finally, an optimized system simulation was conducted where the best performing solutions were combined and compared to the reference system. 


\subsection{Key performance indicators}

In order to assess the performance of the system under investigation, some key performance indicators (KPIs) were calculated, which give information about the thermal and electrical performance of the system. The indicators used were suggested by the International Energy Agency - Solar Heating \& Cooling Programme - Task 60 (IEA-SHC-Task 60) [4] and are presented in equations $1-5$. The term heating system (HS) is used for referring to the entire system under investigation except from the PVT panel.

- Solar thermal fraction:

Where:

$$
f_{\text {sol,th }}=\frac{Q_{P V T}}{Q_{\text {sup }, H S}}
$$

$$
Q_{\text {sup }, H S}=Q_{\text {primary }, H P}+Q_{P V T, D H W}
$$

The solar thermal fraction calculates the amount of thermal energy produced by the PVT panel divided by the thermal energy supplied to the heating system.

- Solar electrical fraction:

$$
f_{\text {sol,el }}=\frac{E_{P V T}}{E_{H S}}
$$

The solar electrical fraction calculates the amount of electrical energy produced by the PVT divided by the electrical energy used by the heating system.

- Net renewable energy fraction:

$$
f_{\text {ren }}=\frac{Q_{P V T}+E_{P V T}}{Q_{s u p, H S}+E_{H S}}
$$

The net renewable energy fraction calculates the amount of renewable energy made available (sum of thermal and electrical energy produced by the PVT collector) divided by the total amount of energy used by the heating system.

- Inverse system seasonal performance factor (ISPF):

$$
f_{I S P F}=\frac{E_{H S}-E_{P V T}}{Q_{H S}}
$$

The inverse system performance factor calculates the amount of electricity taken from the grid (if positive) or the amount of electricity fed to the grid (if negative). The reason for using the inverse SPF was that, in some of the investigated cases, the generated amount of solar electricity was larger than the demand of the heating system. That gave negative SPF, which had no physical meaning.

\section{Results and discussion}

Initially, the results from the validation of the simulation model is presented. Afterwards results from simulations over a year is presented via selected KPIs including the parameter variation on components sizes and system improvements. 


\subsection{Validation}

427 Each component of the system was validated individually. Having specified the particular coefficients of each component, the full model was also validated.

The collector loop, the heat pump including the pipe loops to the connected tanks and the two storage tanks were validated separately.

\subsubsection{Photovoltaic-thermal collector model validation}

The daily accumulated measured and simulated electrical and thermal output of the PVT collector is displayed in Figure 3. The deviation between the measured and calculated energy quantities were less than $1 \%$ over the entire measurement period. On a monthly basis, the deviations were less than $5 \%$, except for the electrical output in the winter period, where the output was very low and the relative deviation therefore was higher.

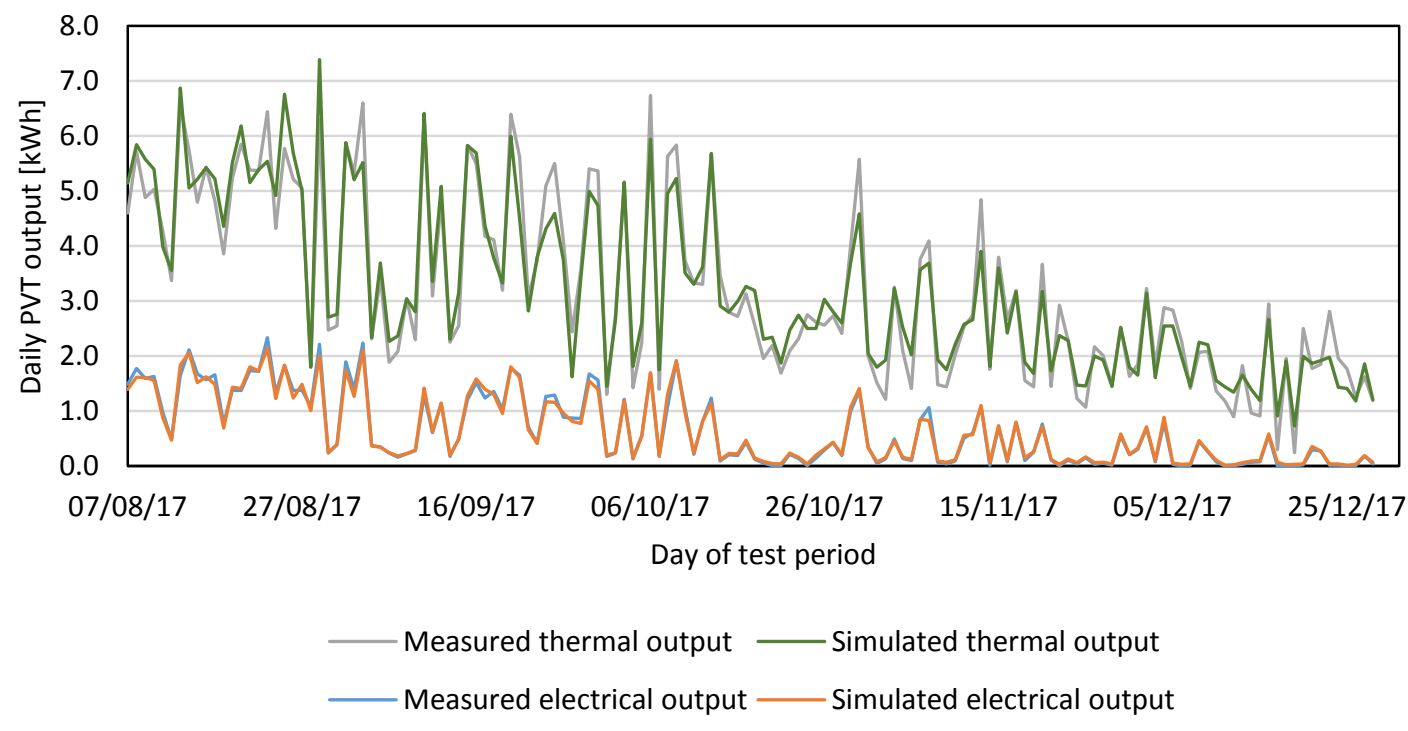

3.1.1.2 Heat pump

441 The measured and simulated electrical consumption and the thermal load output from the heat pump were compared over the test period in Figure 4. Over a monthly basis, the deviations between measurement and calculations were less than $4 \%$. 


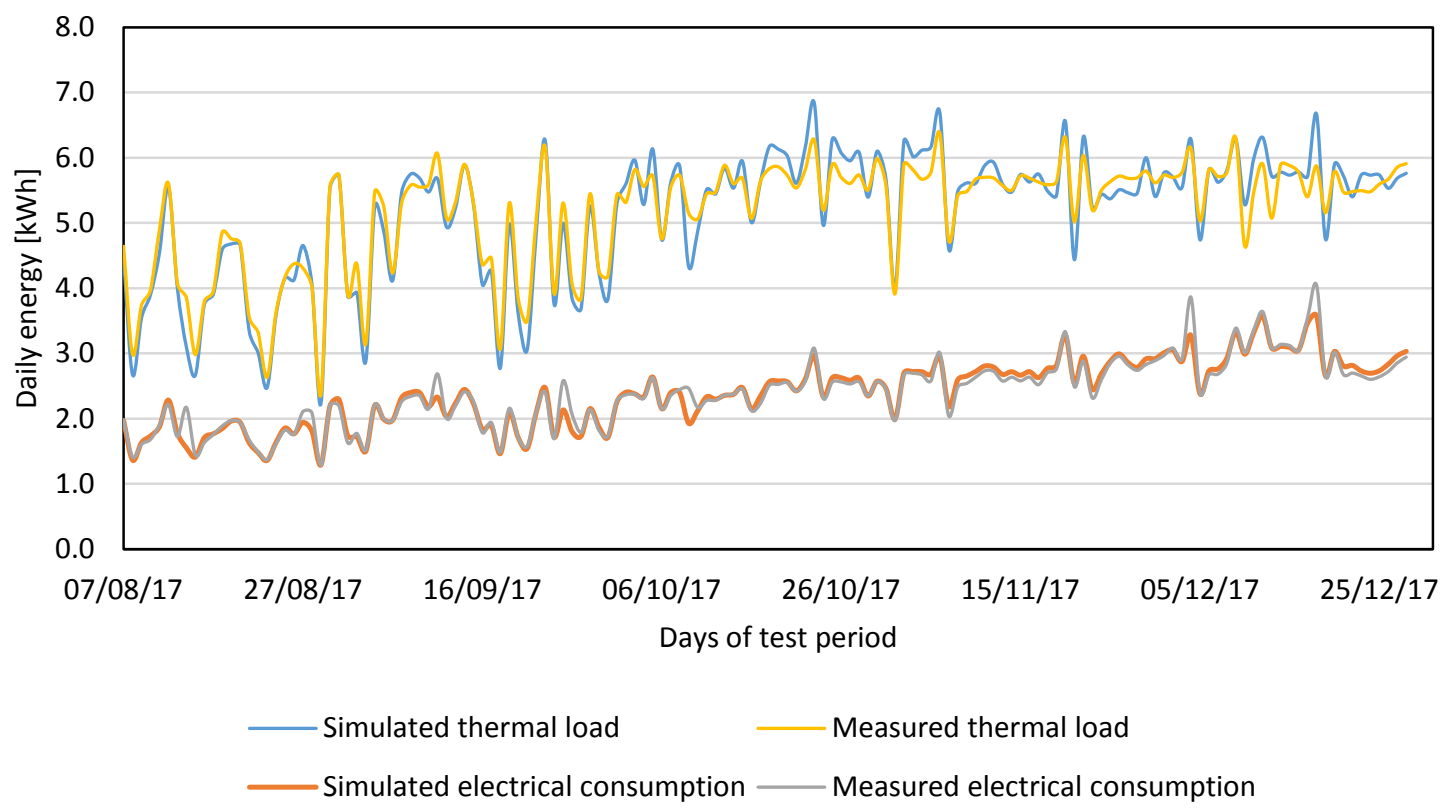

444

Figure 4: Measured and simulated daily electrical power consumption and thermal load delivered by pipe loop.

\subsubsection{Buffer tank and domestic hot water tank}

Several 7-9 hour periods, where there was no flow though the tanks, were used to match the simulated heat losses from the tanks to the measurement.

The temperature in the buffer tank was typically lower than the indoor temperature and therefore heat was passively supplied to the tank in the standby periods. The heat loss coefficients of the sides, top and bottom were set so that the measurement of the temperature development in the tank matched the simulated. The heat gain from the thermosiphon described in section 2.2.1.3 was included in the heat loss coefficient for the upper tank layer. The heat loss coefficient at the top of the buffer tank was set to $0.8 \mathrm{~W} /{ }^{\circ} \mathrm{C}$, and the nodal edge heat loss coefficient at node 1 to $1.1 \mathrm{~W} /{ }^{\circ} \mathrm{C}$. The total heat loss coefficient for the remaining tank side was set to $2 \mathrm{~W} /{ }^{\circ} \mathrm{C}$ and for the bottom to $1.4 \mathrm{~W} /{ }^{\circ} \mathrm{C}$. A miscellaneous heat gain of $30 \mathrm{~W}$ was added to the upper part of the tank model (node 5 ), to compensate for the passive heat gain from the heat pump due to the thermosiphon in the standby periods. That way the measured temperature development in the tank matched the calculated temperature development in standby periods both in situations where the temperature in the tank was close to the ambient indoor temperature and in cases where the temperature in the buffer tank was significantly lower than the indoor temperature. For the DHW tank the top heat loss coefficient was set to $0.8 \mathrm{~W} /{ }^{\circ} \mathrm{C}$, side to $1.9 \mathrm{~W} /{ }^{\circ} \mathrm{C}$, and the bottom to $0.2 \mathrm{~W} /{ }^{\circ} \mathrm{C}$.

Figure 5 and Figure 6 , show the measured and simulated temperature developments in the top, middle and bottom of the DHW and buffer tanks during a 6 hours standby period. There were minor deviations between the measured and simulated temperatures in the middle of the DHW tank in the first part of the period. 


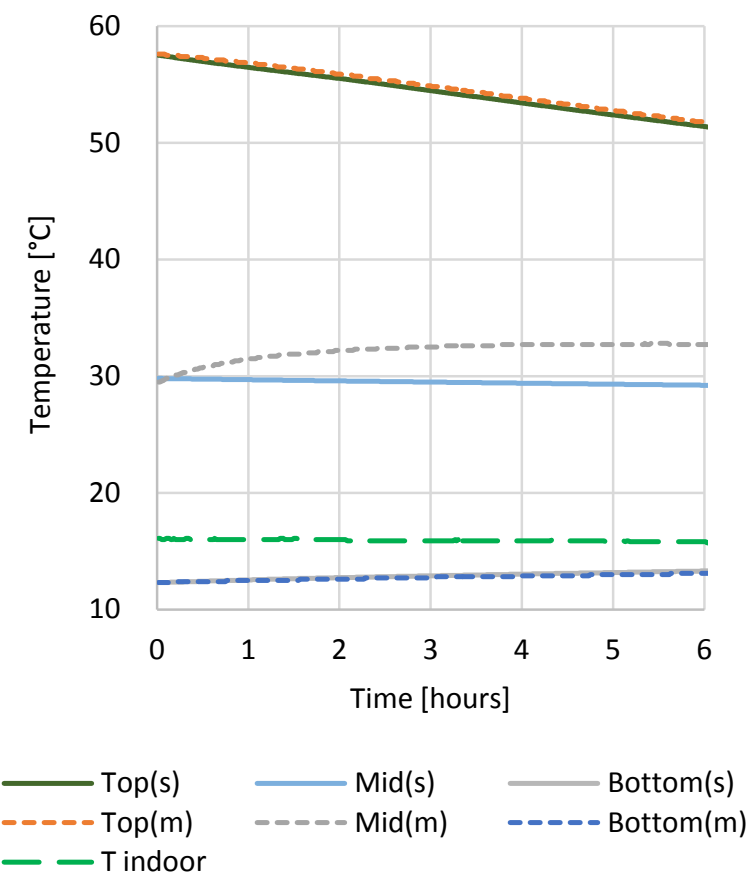

Figure 5: Measured $(m)$ and simulated $(s)$ temperature development in the DHW tank in standby period.

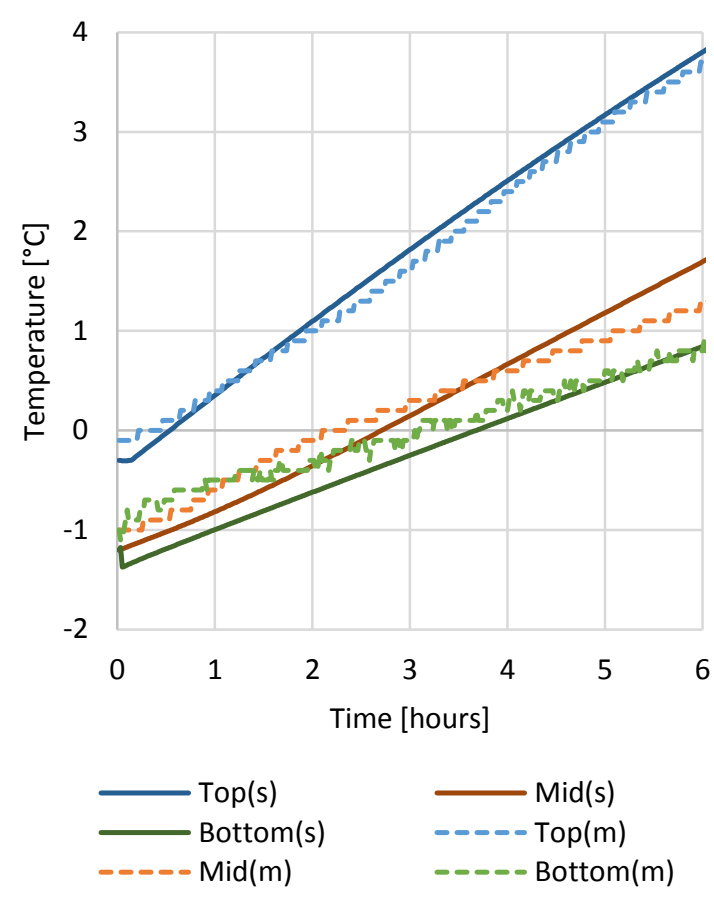

Figure 6: Measured $(\mathrm{m})$ and simulated $(\mathrm{s})$ temperature development in the buffer tank in standby period.
467

468

469

470

471

472

473

474

\subsubsection{Full model validation}

The measured and simulated energy transfer at key locations in the system were used to validate the full model against the measurements. Table 3 shows the measured and simulated energy quantities for tapped DHW, thermal and electrical output of the PVT collector, electrical consumption of the heat pump, heat delivered to the DHW tank by the heat pump and heat extracted from the buffer storage by the heat pump.

Table 3: Measured (M) and simulated (S) energy quantities in kWh/day for full model validation.

\begin{tabular}{|c|c|c|c|c|c|c|}
\hline Month & $\begin{array}{l}\text { Thermal } \\
\text { collector } \\
\text { output } \\
\text { [kWh/day] }\end{array}$ & $\begin{array}{c}\text { Tapped } \\
\text { DHW } \\
{[\mathrm{kWh} / \text { day }]}\end{array}$ & $\begin{array}{l}\text { PV electrical } \\
\text { output } \\
\text { [kWh/day] }\end{array}$ & $\begin{array}{l}\text { Heat pump } \\
\text { electrical } \\
\text { consumption } \\
\text { [kWh/day] }\end{array}$ & $\begin{array}{c}\text { Heat } \\
\text { delivered to } \\
\text { DHW by } \\
\text { heat pump } \\
\text { [kWh/day] }\end{array}$ & $\begin{array}{c}\text { Heat } \\
\text { extracted } \\
\text { from buffer } \\
\text { storage by } \\
\text { heat pump } \\
\text { [kWh/davl }\end{array}$ \\
\hline
\end{tabular}

\begin{tabular}{ccccccccccccc} 
& $\mathrm{M}$ & $\mathrm{S}$ & $\mathrm{M}$ & $\mathrm{S}$ & $\mathrm{M}$ & $\mathrm{S}$ & $\mathrm{M}$ & $\mathrm{S}$ & $\mathrm{M}$ & $\mathrm{S}$ & $\mathrm{M}$ & $\mathrm{S}$ \\
\hline Aug. & 5.16 & 5.16 & 4.3 & 4.52 & 1.52 & 1.53 & 1.74 & 1.84 & 4.04 & 3.96 & 4.4 & 4.64 \\
Sept. & 4 & 3.98 & 4.35 & 4.32 & 0.92 & 0.92 & 2.05 & 2.12 & 4.95 & 4.85 & 5.06 & 5.12 \\
Oct. & 3.29 & 3.27 & 4.33 & 4.52 & 0.57 & 0.55 & 2.38 & 2.31 & 5.19 & 5.47 & 5.49 & 5.26 \\
Nov. & 2.25 & 2.32 & 4.43 & 4.47 & 0.32 & 0.3 & 2.65 & 2.65 & 5.33 & 5.57 & 5.47 & 5.25 \\
Dec. & 1.74 & 1.81 & 4.52 & 4.51 & 0.22 & 0.19 & 3.14 & 2.97 & 5.46 & 5.65 & 5.39 & 5.14 \\
Total & 16.4 & 16.5 & 21.9 & 22.3 & 3.6 & 3.5 & 12.0 & 11.9 & 25.0 & 25.5 & 25.8 & 25.4 \\
\hline
\end{tabular}


Table 4 illustrates the deviations between the previously mentioned quantities. It can be observed that the deviations between the measured and simulated values were less than $6 \%$ for each period and key location except for the electrical output of the PVT collector in December, similar as in the part collector model.

Table 4: Deviations between the simulated and the measured energy quantities for full model validation.

\begin{tabular}{ccccccc}
\hline Month & $\begin{array}{c}\text { Thermal } \\
\text { collector } \\
\text { output }\end{array}$ & $\begin{array}{c}\text { Tapped } \\
\text { DHW }\end{array}$ & $\begin{array}{c}\text { PV } \\
\text { electrical } \\
\text { output }\end{array}$ & $\begin{array}{c}\text { Heat pump } \\
\text { electrical } \\
\text { consumption }\end{array}$ & $\begin{array}{c}\text { Heat } \\
\text { delivered } \\
\text { to DHW by } \\
\text { heat pump }\end{array}$ & $\begin{array}{c}\text { Heat } \\
\text { extracted } \\
\text { from buffer } \\
\text { storage by } \\
\text { heat pump }\end{array}$ \\
\hline Aug. & $0 \%$ & $5 \%$ & $1 \%$ & $5 \%$ & $-2 \%$ & $5 \%$ \\
Sept. & $-1 \%$ & $-1 \%$ & $0 \%$ & $3 \%$ & $-2 \%$ & $1 \%$ \\
Oct. & $-1 \%$ & $4 \%$ & $-3 \%$ & $-3 \%$ & $5 \%$ & $-4 \%$ \\
Nov. & $3 \%$ & $1 \%$ & $-6 \%$ & $0 \%$ & $5 \%$ & $-4 \%$ \\
Dec. & $4 \%$ & $0 \%$ & $-14 \%$ & $-6 \%$ & $3 \%$ & $-5 \%$ \\
Total & $1 \%$ & $2 \%$ & $-1 \%$ & $-1 \%$ & $2 \%$ & $-2 \%$ \\
\hline
\end{tabular}

\subsection{Yearly performance}

The simulated yearly performance of the system is presented. First by showing the effect on the KPIs by varying the component sizes. Followed by the effect of including the system improvements and lastly the performance of the original system is compared to the improved system with selected component sizes.

\subsubsection{Parameter variation results}

In Figure 7 to Figure 10, selected KPIs are presented for PVT collector size, buffer and DHW storage tank volumes, as well as the results for parameter variation of these components. The existing (reference) system is presented by the orange bar in all figures and its level is also indicated by a dashed black line. Figure 7 shows the solar thermal fraction for the system including the parameter variation. 


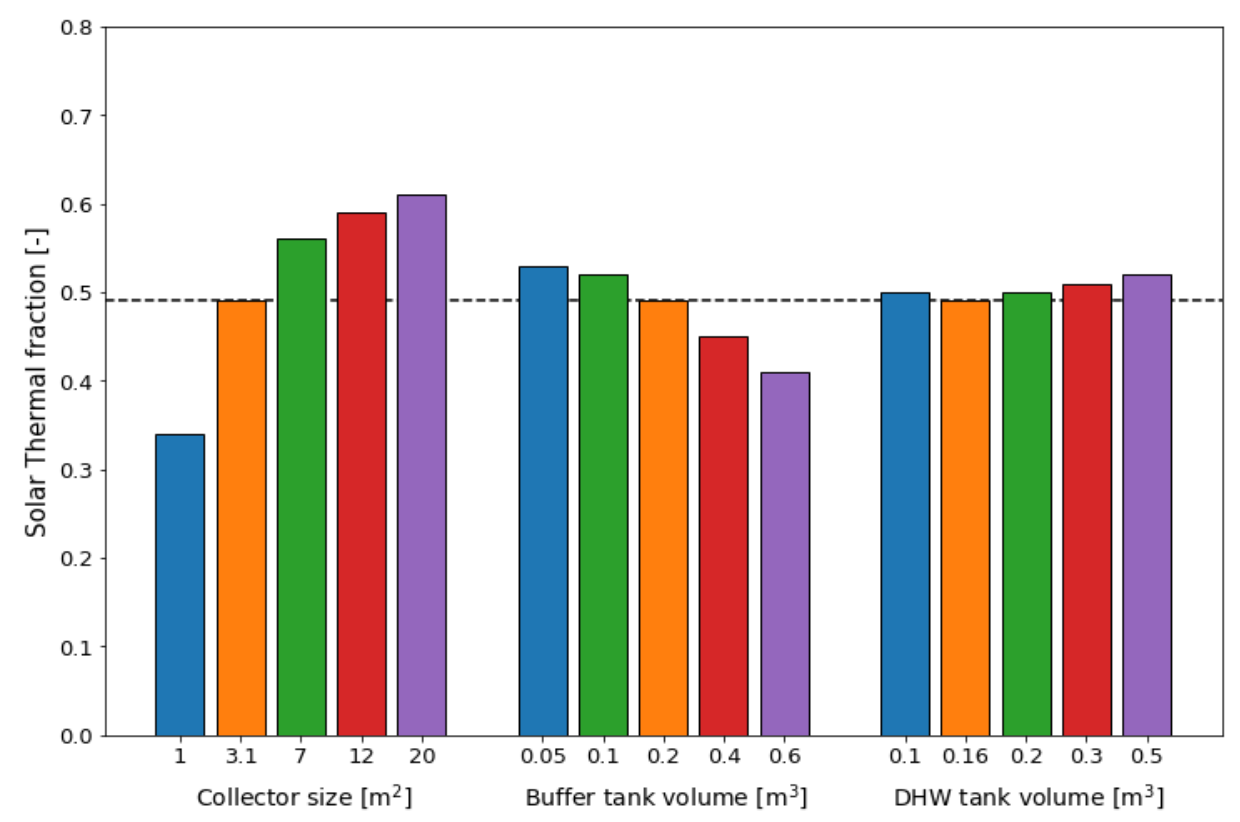

Figure 7: Solar thermal fraction for collector size, buffer and DHW tank volume parametric analysis.

The reference system's solar thermal fraction was 0.49 . In Figure 7, it can be observed that using a larger PVT collector area, the solar thermal fraction of the system can be improved. Calculating the thermal fraction increase over the collector area, a $2 \%$ fraction increase per $\mathrm{m}^{2}$ was found when increasing from 3.1 to $7 \mathrm{~m}^{2}$. A $1 \%$ and $0.5 \%$ fraction increase per $\mathrm{m}^{2}$ was found when increasing the collector area from 7 to 12 and 12 to $20 \mathrm{~m}^{2}$, respectively. This indicates that as the collector area becomes larger less and less of the additional heat produced would be utilized by this system.

The obtained results indicate that the smallest volume of buffer tank tested led to the highest solar thermal fraction. Normally, a larger buffer tank would provide a larger heat source for the heat pump leading to improved performance of the system. In this system though, since the buffer tank was not well insulated, the temperature of the buffer tank was highly influenced by the indoor temperature. For this reason, a smaller tank is heated easier by the indoor temperature compared to a big tank, especially in the winter period where the ability of the PVT collector to heat the tank is limited. When running the simulations for buffer tanks smaller than 200 liters it was noticed that the temperature of the buffer tank could reach very low levels (e.g. up to $-15^{\circ} \mathrm{C}$ ) when the heat pump was in operation. However, in reality, the heat pump has a safety mechanism which shuts down the heat pump when the source temperatures are below $-7{ }^{\circ} \mathrm{C}$ and uses an electrical heater to heat up the DHW tank instead. Since small buffer tanks reached temperature levels lower than $-7{ }^{\circ} \mathrm{C}$, an electrical heater was implemented in the DHW tank to simulate this behavior. The thermal performance of the system remained unchanged with this modification but the electricity consumption of the system was affected.

Regarding the DHW tank, it seems that the solar thermal fraction is barely affected by a change in the tank volume. This however means that a smaller (thus cheaper) tank could be used in the system without affecting its operation and performance.

The results obtained by the simulation and parameter variations suggest that the system under investigation is probably over-dimensioned, since smaller tanks would increase its thermal performance.

Figure 8 shows the solar electrical fraction for the system including the parameter variation. 


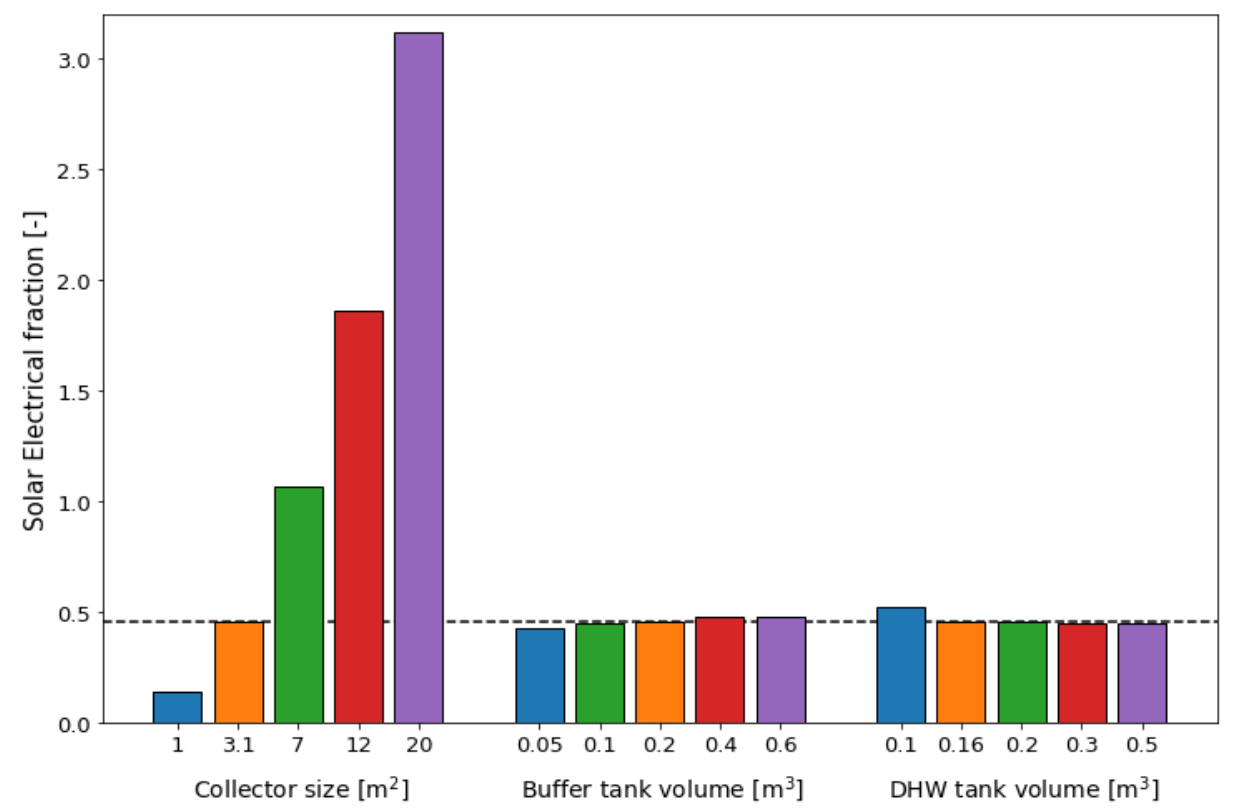

Figure 8: Solar electrical fraction for collector size, buffer and DHW tank volume parametric analysis.

The solar electrical fraction of the reference system was 0.46 . As it can be seen in Figure 8 , an increase in the PVT collector's area can cause a very steep increase in the solar electrical fraction, due to larger electrical production. It can be observed that buffer tanks smaller than 200 liters decreased the solar electrical fraction of the system. The reason is as described before that, an electrical heater was used during some periods in the winter where the buffer tank temperature reached temperatures below $-7{ }^{\circ} \mathrm{C}$. This led to higher electricity consumption and thus lower solar electrical fraction. On the contrary, a smaller DHW tank increased marginally the solar electrical fraction due to less operation of the heat pump in order to charge the tank.

From Figure 7 and Figure 8 , it can be observed that a larger collector area is always beneficial regarding electricity production while there is a limit in how much thermal energy from the PVT collector can be utilized by the system. This suggests that, from a certain collector area and on, it might be more beneficial to install PV panels instead of increasing the PVT area.

Figure 9 shows the net renewable energy fraction for the system including the parameter variation 


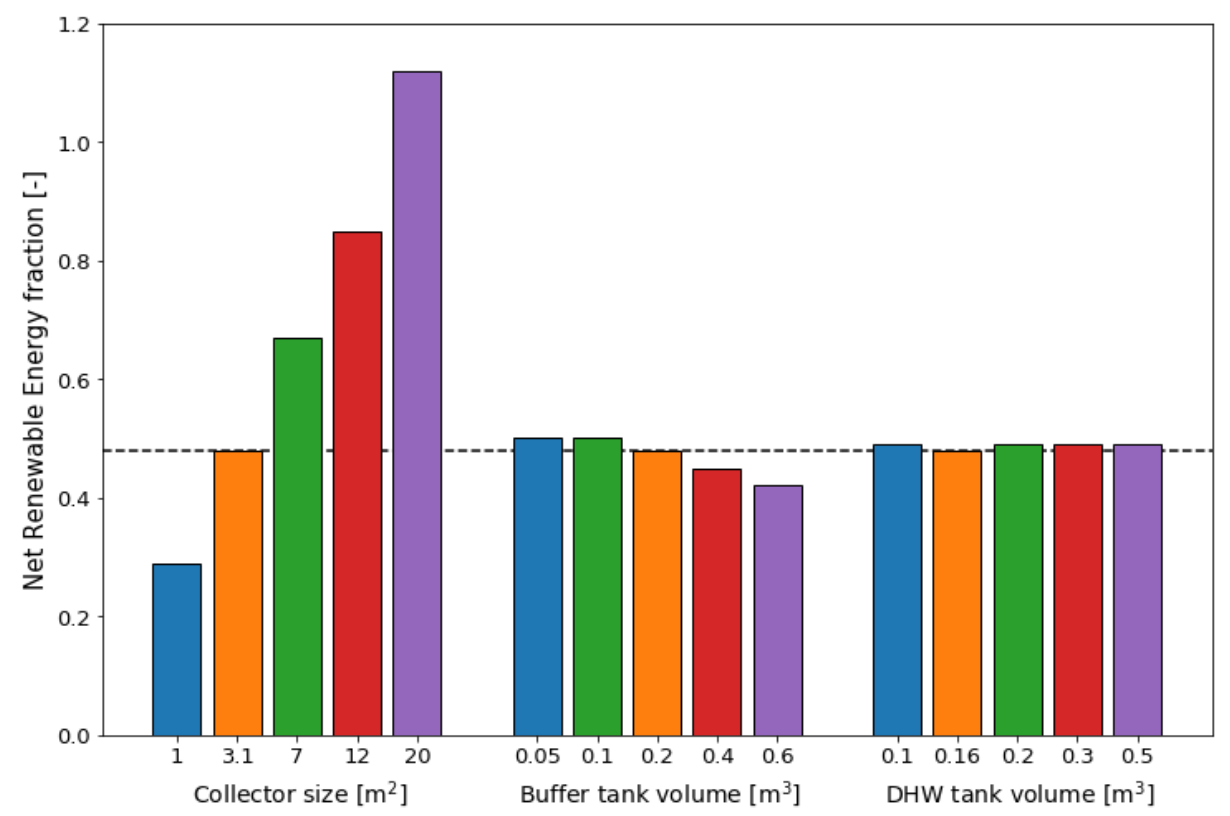

Figure 9: Net renewable energy fraction for collector size, buffer and DHW tank volume parametric analysis.

The net renewable energy fraction of the reference system was 0.48 . In Figure 9 , it can be observed that an increase in the PVT collector area increases the renewable energy fraction dramatically, since the system produces more thermal and electrical energy. A smaller buffer tank increases marginally the net renewable energy fraction, because it decreases the available energy amount to the heat pump source, making the fraction larger. The parameter variation on the DHW volume had almost no effect on this KPI.

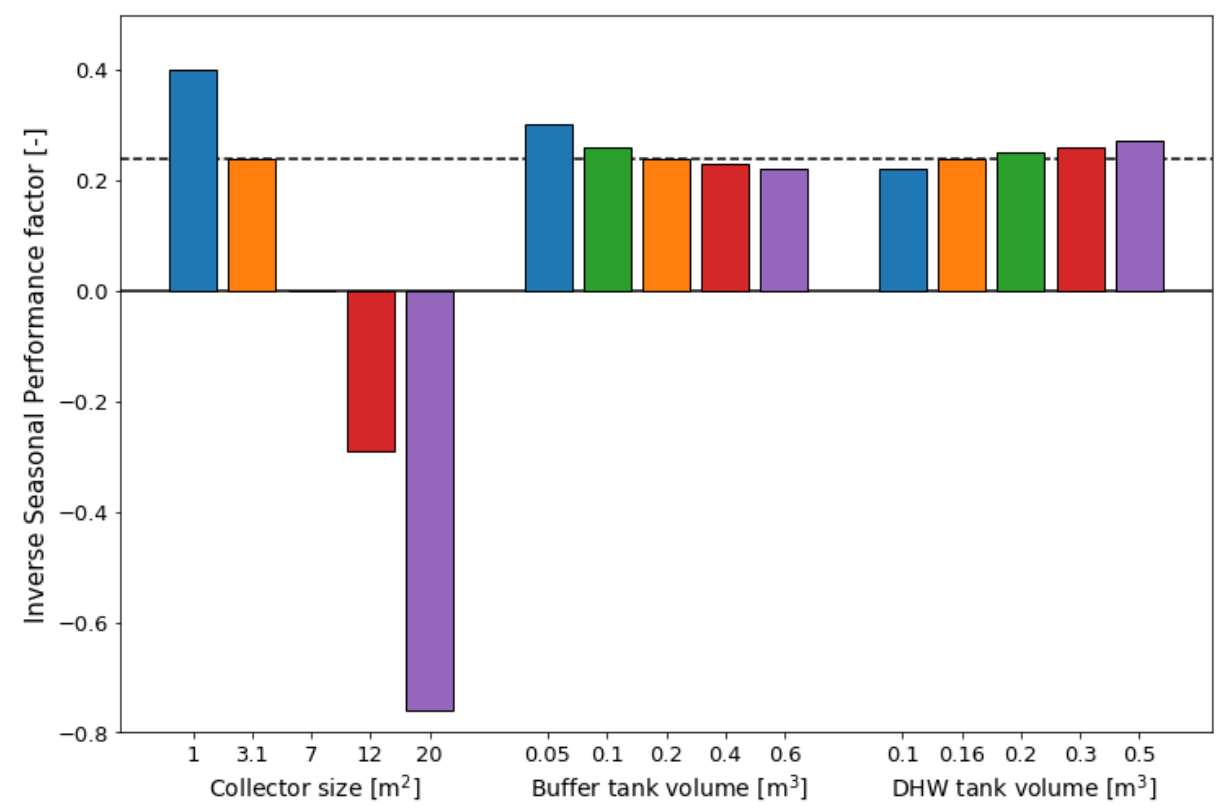

Figure 10: Inverse seasonal performance factor for collector size, buffer and DHW tank volume parametric analysis.

The inverse seasonal performance factor of the reference system was 0.24 . This indicator shows the amount of electricity the system uses per unit of provided heat (positive values) or the amount of electricity the system feds to the grid per unit of provided heat (negative values). So, contrary to the previously mentioned fractions, a lower value of this factor is considered more beneficial for the system performance. 


\section{8}

The only scenarios that produce more electricity than needed are the cases with the collector areas larger than $7 \mathrm{~m}^{2}$. It can be observed that the small buffer tanks, which use the electrical heater in the winter, have a worse performance factor than the larger tanks. On the contrary, smaller DHW tanks performed better due to less operation of the heat pump and thus less electricity consumption.

\subsubsection{System improvements}

Apart from the parameter variation of the system components, some improvement scenarios were investigated for the reference system regarding insulation, pipe length and heat exchanger height. The pipe length between the heat pump and the tanks in the reference system were $4 \times 6 \mathrm{~m}$ and in the TRNSYS model, another $21 \mathrm{~m}$ were added for including the thermal mass of the heat pump. In addition, the DHW tank top heat losses were $0.8 \mathrm{~W} /{ }^{\circ} \mathrm{C}$ and the DHW tank heat exchanger height equal to $0.6 \mathrm{~m}$.

The physical placement of the components in the demonstration system was not optimal, leading to long pipe loops between the heat pump and the storage tanks. A possible improvement scenario was a decrease of pipe length between the tanks and the heat pump by placing them closer together. Also, the DHW tank had two pipes exiting the top of the tank, creating thermal bridges and losses from the top of the tank. An improved scenario for this case could either be a better insulated top of the DHW tank or a different tank where there would be no pipes exiting the top. Lastly, the heat exchanger of the DHW tank connected to the heat pump, was able to charge only the upper part of the tank. Since the heat pump operation was short, it was considered interesting to investigate a scenario where the heat exchanger was reaching the bottom of the tank, so that the heat pump was able to charge the entire tank. For these reasons, three scenarios were investigated; namely one with reducing the $4 \times 6 \mathrm{~m}$ pipes to $4 \times 1 \mathrm{~m}$ (keeping the $21 \mathrm{~m}$ for the heat pump thermal mass), one with the DHW tank top heat losses of $0.2 \mathrm{~W} /{ }^{\circ} \mathrm{C}$ and one with the height of the upper DHW tank heat exchanger of $1.2 \mathrm{~m}$. The results are presented in Table 5.

Table 5: KPIs for pipe length, DHW top heat loss and DHW tank heat exchanger height variations.

\begin{tabular}{ccccc}
\hline & $\begin{array}{c}\text { Solar thermal } \\
\text { fraction }\end{array}$ & $\begin{array}{c}\text { Solar electrical } \\
\text { fraction }\end{array}$ & $\begin{array}{c}\text { Net Renewable } \\
\text { Energy fraction }\end{array}$ & ISPF \\
\hline Reference system & 0.49 & 0.46 & 0.48 & 0.24 \\
$\begin{array}{c}\text { Total pipe length of } 4 \mathrm{~m} \\
\text { DHW tank top heat loss of } 0.2\end{array}$ & 0.51 & 0.54 & 0.51 & 0.19 \\
$\mathrm{~W} /{ }^{\circ} \mathrm{C}$ & 0.49 & 0.50 & 0.49 & 0.20 \\
Heat Exchanger height of $1.2 \mathrm{~m}$ & 0.50 & 0.48 & 0.48 & 0.24 \\
\hline
\end{tabular}

It can be observed that shorter pipe length improved all KPIs for the system, indicating that the pipe losses are high. By increasing the DHW tank top insulation, only the solar electrical fraction and ISPF were improved significantly, indicating that the electrical performance of the system is improved having the same thermal performance. This can lead to the conclusion that the tank losses from the DHW tank were high. By better insulating the DHW tank, the heat pump operation for charging the tank would be decreased (leading to lower electricity consumption), thus improving the electrical performance of the system. Lastly, a larger heat exchanger in the DHW tank that could charge the entire tank seems to increase marginally the performance of the system, probably due to more optimal operation of the heat pump.

\subsubsection{System performance}


In general it could be stated that the component that affected the performance of the system the most, based on the studied KPIs, was the PVT collector area. A $7 \mathrm{~m}^{2}$ was selected for the improved system since for larger collector areas the heat produced were only to a small extend utilized by the system.

It was decided to use the existing buffer tank for the improved system. The reason was that, although a smaller buffer tank increased the thermal fraction by $8 \%$ and the renewable fraction by $4 \%$, at the same time it decreased the electrical fraction by $7 \%$ and the system performance factor by $25 \%$. On the contrary, a smaller DHW tank seemed to perform equally well, thus it was decided to use a smaller one. Although in this study, the cost of the components was not included in the calculations, the choice of component sizes for the improved system was done having in mind that smaller component sizes have also lower costs.

For this reason, the decided optimized system consisted of a $7 \mathrm{~m}^{2}$ PVT collector, $0.2 \mathrm{~m}^{3}$ buffer tank, $0.1 \mathrm{~m}^{3} \mathrm{DHW}$ tank, DHW top heat loss of $0.2 \mathrm{~W} /{ }^{\circ} \mathrm{C}$, a pipe lengths between heat pump and tanks of 4 $\mathrm{x} 1 \mathrm{~m}$ and a DHW tank heat exchanger height of $1.2 \mathrm{~m}$. The results of the optimized system compared to the reference system are presented in Table 6 and Table 7.

\begin{tabular}{ccccccc}
\hline & $\begin{array}{c}\text { Heat to } \\
\text { DHW from } \\
\text { PVT [kWh] }\end{array}$ & $\begin{array}{c}\text { Heat } \\
\text { output } \\
\text { PVT } \\
{[\mathrm{kWh}]}\end{array}$ & $\begin{array}{c}\text { Electrical } \\
\text { output } \\
\text { from PVT } \\
{[\mathrm{kWh}]}\end{array}$ & $\begin{array}{c}\text { Heat pump } \\
\text { electric } \\
\text { consumption } \\
{[\mathrm{kWh}]}\end{array}$ & $\begin{array}{c}\text { Heat to } \\
\text { DHW from } \\
\text { heat pump } \\
{[\mathrm{kWh}]}\end{array}$ & $\begin{array}{c}\text { Heat } \\
\text { extracted } \\
\text { from buffer } \\
\text { tank by heat } \\
\text { pump [kWh] }\end{array}$ \\
\hline $\begin{array}{c}\text { Reference } \\
\text { system } \\
\begin{array}{c}\text { Improved } \\
\text { system }\end{array}\end{array}$ & 135 & 1089 & 296 & 699 & 1748 & 1979 \\
\hline \multicolumn{7}{l}{ Table 6: Key parameters regarding operation of reference and optimized system. }
\end{tabular}

604

Table 6: Key parameters regarding operation of reference and optimized system.

The optimized system PVT collector area was $56 \%$ larger than the reference system's. That led to $55 \%$ higher electricity production by the PVT collector. However, it can be observed that the heat output from the two collectors was very similar, indicating that the larger collector operated less time, as there were longer periods where the heat produced by the collector cannot be utilized by the system. Also, even in the optimized system, the amount of heat that was transferred directly from the PVT collector to the DHW tank was quite small on a yearly basis. This can be explained by the unglazed PVT collector can produce water temperatures around $30^{\circ} \mathrm{C}$, while the temperature in the top of the DHW tank should be at $50{ }^{\circ} \mathrm{C}$. This temperature difference makes the direct charge of the DHW tank limited even in the optimized scenario.

Due to lower system losses and higher source temperatures, the heat pump operation was improved in the optimized system leading to $23 \%$ lower electric consumption. Also, $11 \%$ less heat was necessary to be transferred to the DHW tank by the heat pump, since the heat from the PVT collector had been utilized more and the DHW tank and pipes had lower heat losses. optimized system fed electricity to the grid for every unit of heat provided, unlike the reference system. 
Table 7: KPIs for reference and improved system.

\begin{tabular}{ccccc}
\hline & $\begin{array}{c}\text { Solar Thermal } \\
\text { fraction }\end{array}$ & $\begin{array}{c}\text { Solar Electrical } \\
\text { fraction }\end{array}$ & $\begin{array}{c}\text { Net Renewable } \\
\text { Energy fraction }\end{array}$ & $\begin{array}{c}\text { Inverse Seasonal } \\
\text { Performance Factor }\end{array}$ \\
\hline $\begin{array}{c}\text { Reference } \\
\text { system } \\
\text { Improved } \\
\text { system }\end{array}$ & 0.49 & 0.46 & 0.48 & 0.24 \\
\hline
\end{tabular}

623

624

625

626

627

628

629

630

631

632

633

634

635

636

637

638

639

640

641

642

643

644

645

646

647

648

649

650

651

652

653

654

655

656

It was noticed that even in the case of the improved system, a large amount of heat could not be utilized for various reasons (e.g. the temperature of the buffer and DHW tank was high during periods of sunshine thus no tank could be charged). That could potentially be solved by adding another tank for space heating purposes.

In the present study, no economic KPIs were calculated. The reason is that, since this system was only used for producing DHW, it was not financially attractive due to its high cost for covering such a low hot water demand. For this reason, it is firmly believed that the investigated system should be used also for space heating purposes if it is to become financially attractive. However, it has to be stated that the component sizes selected for the optimized system are likely to be different if the system is also used for providing space heating.

\subsection{Perspective}

The investigations showed that the principle of using a buffer storage tank, which was charged via a PVT collector, as the source for a liquid-to-liquid heat pump can work. This potentially allows for having heating systems with high performance without having the need for installing a ground sourced heat exchanger which may be more costly and space consuming to install. The correct sizing of the components related to the required load for the system is essential. The investigations in this study showed that with only a DHW load the system was oversized. Therefore it is suggested that for future investigations the focus should be on systems with larger loads, potentially combined DHW and space heating or for multifamily houses. The developed model can be a basis for future investigations of system with better system size with respect to load.

Under sizing the storage tank at the source side of the heat pump may lead to undesired low temperatures for the source for the heat pump, which may cause the heat pump to go into safety mode and use electricity directly for heating. With a proper sized system, the concept may allow for having performances better that air-to-liquid heat pump systems at a lower cost than systems with heat pumps and ground sourced heat exchanger. Compared to SAHP systems with the solar collector directly as the source for the heat pumps, the system with the buffer tank does allow for higher inlet temperatures for the source side of the heat pump which can increase the heat pump performance. This may be during a cold night after a sunny day where heat extracted by solar collectors can be stored in the buffer tank until the night. Further, the study showed that the uninsulated PVT collector could be used to charge the buffer storage tank in situations without any useful solar irradiance available e.g. after the heat pump had operated and the buffer storage temperature dropped below the ambient air temperature. 


\section{Conclusions}

A novel heating system consisting of heat pump, PVT collector, buffer tank and DHW tank for supplying a single family house in Denmark with domestic hot water was investigated. Experimental investigations of the system occurred from August to December 2017 at the test facilities of the Technical University of Denmark (DTU). The measurement period was used for validating a TRNSYS model of the system, which was later used for performing a yearly simulation of the system with Danish reference conditions. Key Performance Indicators (KPIs) were calculated in order to evaluate the system's thermal and electrical performance. A parameter variation of the sizes of the system's components (PVT collector area, buffer and DHW tank volume) was performed in order to identify a combination for higher performance. The key findings of the study were:

- For a system that produces only DHW, the thermal performance of the system increased when the size of the buffer and the DHW tank were the smallest investigated; namely 0.05 and $0.1 \mathrm{~m}^{3}$ respectively. This indicated that the system under investigation was probably over-dimensioned and should be further investigated for providing space heating as well.

- A larger heat exchanger in the DHW tank that can charge the entire tank volume can benefit the system regarding performance due to more optimal operation of the heat pump.

- The suggested improved system produced 55\% more electricity, had $23 \%$ lower electric consumption and wasted $11 \%$ less heat by minimizing heat losses. It consisted of a $7 \mathrm{~m}^{2} \mathrm{PVT}$ collector, $0.2 \mathrm{~m}^{3}$ buffer tank, $0.1 \mathrm{~m}^{3} \mathrm{DHW}$ tank, DHW top heat loss of $0.2 \mathrm{~W} /{ }^{\circ} \mathrm{C}$, pipe lengths of $4 \times 1 \mathrm{~m}$ between the heat pump and tanks and a heat exchanger height of $1.2 \mathrm{~m}$.

The investigations have shown that the principle of having a buffer storage tank, which can be charged by an uncovered PVT collector, as the source of the heat pump works. Every time the heat pump ran and discharged the buffer tank, it was recharged by the PVT collectors to the temperature level of the ambient air even in situations without solar irradiance available. The results indicate that the performance of a system can be dramatically improved by choosing appropriate-sized components. However, the optimal size of the components depends on the use of the system and thus it can be challenging to be identified before the realization of the system. Further, for a system with this complexity, the load needs to be larger than what was presented in this study in order to make the system economically attractive.

\section{Acknowledgement}

The research was financed by the Danish Energy Agency through EUDP grant no. 64017-05157 and Bjarne Saxhofs Fond.

\section{References}

[1] The European Commission, "Heating and cooling - European Commission," 2018. [Online]. Available: https://ec.europa.eu/energy/en/topics/energy-efficiency/heating-and-cooling. [Accessed: 08-Oct-2018].

[2] Z. Tian et al., "Large-scale solar district heating plants in Danish smart thermal grid: Developments and recent trends," Energy Conversion and Management, vol. 189. pp. 67-80, 
Jun-2019.

[3] M. D'Antoni, R. Fedrizzi, and W. Sparber, "IEA - SHC Task 44 / HPP Annex 38 Solar and Heat Pump Systems - Industry Newsletter - Second issue," 2012.

[4] "IEA SHC || Task 60 || IEA SHC || Task 60." [Online]. Available: http://task60.iea-shc.org/. [Accessed: 19-Oct-2019].

[5] E. Bellos, C. Tzivanidis, K. Moschos, and K. A. Antonopoulos, "Energetic and financial evaluation of solar assisted heat pump space heating systems," Energy Convers. Manag., vol. 120, pp. 306-319, 2016.

[6] F. M. Rad, A. S. Fung, and W. H. Leong, "Feasibility of combined solar thermal and ground source heat pump systems in cold climate, Canada," Energy Build., vol. 61, pp. 224-232, 2013.

[7] A. Buonomano, F. Calise, A. Palombo, and M. Vicidomini, "BIPVT systems for residential applications: An energy and economic analysis for European climates," Appl. Energy, vol. 184, pp. 1411-1431, 2016.

[8] J. P. Fine, J. Friedman, and S. B. Dworkin, "Detailed modeling of a novel photovoltaic thermal cascade heat pump domestic water heating system," Renew. Energy, vol. 101, pp. 500-513, 2017.

[9] F. Busato, R. Lazzarin, and M. Noro, "Ground or solar source heat pump systems for space heating: Which is better? Energetic assessment based on a case history," Energy Build., vol. 102, pp. 347-356, 2015.

[10] M. Lämmle, A. Oliva, M. Hermann, K. Kramer, and W. Kramer, "PVT collector technologies in solar thermal systems: A systematic assessment of electrical and thermal yields with the novel characteristic temperature approach," Sol. Energy, vol. 155, pp. 867-879, 2017.

[11] A. Zarrella, G. Emmi, J. Vivian, L. Croci, and G. Besagni, "The validation of a novel lumped parameter model for photovoltaic thermal hybrid solar collectors: a new TRNSYS type," Energy Convers. Manag., vol. 188, pp. 414-428, May 2019.

[12] F. Calise, M. Dentice D'accadia, D. Figaj, and L. Vanoli, “Thermoeconomic optimization of a solar-assisted heat pump based on transient simulations and computer Design of Experiments," 2016.

[13] G. Emmi, A. Zarrella, and M. De Carli, "A heat pump coupled with photovoltaic thermal hybrid solar collectors: A case study of a multi-source energy system," Energy Convers. Manag., vol. 151, pp. 386-399, Nov. 2017.

[14] H. Jouhara et al., "The performance of a heat pipe based solar PV/T roof collector and its potential contribution in district heating applications," Energy, vol. 136, pp. 117-125, Oct. 2017.

[15] P. Dupeyrat, C. Ménézo, and S. Fortuin, "Study of the thermal and electrical performances of PVT solar hot water system," Energy Build., vol. 68, pp. 751-755, Jan. 2014.

[16] D. Gürlich, A. Dalibard, and U. Eicker, "Photovoltaic-thermal hybrid collector performance for direct trigeneration in a European building retrofit case study," Energy Build., vol. 152, pp. 701-717, Oct. 2017.

[17] J. F. Chen, L. Zhang, and Y. J. Dai, "Performance analysis and multi-objective optimization of a hybrid photovoltaic/thermal collector for domestic hot water application," Energy, vol. 143, pp. 500-516, Jan. 2018. 
[18] Y. W. Li, R. Z. Wang, J. Y. Wu, and Y. X. Xu, "Experimental performance analysis on a directexpansion solar-assisted heat pump water heater," Appl. Therm. Eng., vol. 27, no. 17-18, pp. 2858-2868, Dec. 2007.

[19] J. Deng, Z. Tian, J. Fan, M. Yang, S. Furbo, and Z. Wang, "Simulation and optimization study on a solar space heating system combined with a low temperature ASHP for single family rural residential houses in Beijing," Energy Build., vol. 126, pp. 2-13, 2016.

[20] E. I. Sakellariou, A. J. Wright, P. Axaopoulos, and M. A. Oyinlola, "PVT based solar assisted ground source heat pump system: Modelling approach and sensitivity analyses," Sol. Energy, vol. 193, pp. 37-50, Nov. 2019.

[21] M. Aldubyan and A. Chiasson, "Thermal Study of Hybrid Photovoltaic-Thermal (PVT) Solar Collectors Combined with Borehole Thermal Energy Storage Systems," Energy Procedia, vol. 141, pp. 102-108, Dec. 2017.

[22] D. Jonas, G. Frey, and D. Theis, "Simulation and performance analysis of combined parallel solar thermal and ground or air source heat pump systems," Sol. Energy, vol. 150, pp. 500$511,2017$.

[23] H. Li, L. Sun, and Y. Zhang, "Performance investigation of a combined solar thermal heat pump heating system," Appl. Therm. Eng., vol. 71, no. 1, pp. 460-468, 2014.

[24] C. Xi, L. Lin, and Y. Hongxing, "Long term operation of a solar assisted ground coupled heat pump system for space heating and domestic hot water," Energy Build., vol. 43, no. 8, pp. 1835-1844, 2011.

[25] X. Chen and H. Yang, "Performance analysis of a proposed solar assisted ground coupled heat pump system," Appl. Energy, vol. 97, pp. 888-896, 2012.

[26] S. Poppi, C. Bales, M. Y. Haller, and A. Heinz, "Influence of boundary conditions and component size on electricity demand in solar thermal and heat pump combisystems," Appl. Energy, vol. 162, pp. 1062-1073, 2016.

[27] S. Poppi et al., "Analysis of system improvements in solar thermal and air source heat pump combisystems," Appl. Energy, vol. 173, pp. 606-623, 2016.

[28] S. J. Sterling and M. R. Collins, "Feasibility analysis of an indirect heat pump assisted solar domestic hot water system," Appl. Energy, vol. 93, pp. 11-17, 2012.

[29] C. Tzivanidis, E. Bellos, G. Mitsopoulos, K. A. Antonopoulos, and A. Delis, "Energetic and financial evaluation of a solar assisted heat pump heating system with other usual heating systems in Athens," Appl. Therm. Eng., vol. 106, pp. 87-97, 2016.

[30] A. Girard, E. J. Gago, T. Muneer, and G. Caceres, "Higher ground source heat pump COP in a residential building through the use of solar thermal collectors," Renew. Energy, vol. 80, pp. 26-39, 2015.

[31] E. Kjellsson, G. Hellström, and B. Perers, "Optimization of systems with the combination of ground-source heat pump and solar collectors in dwellings," Energy, vol. 35, no. 6, pp. 26672673, 2010.

[32] P. Pärisch, O. Mercker, J. Warmuth, R. Tepe, E. Bertram, and G. Rockendorf, "Investigations and model validation of a ground-coupled heat pump for the combination with solar collectors," Appl. Therm. Eng., vol. 62, no. 2, pp. 375-381, 2014.

[33] S. H. Razavi, R. Ahmadi, and A. Zahedi, "Modeling, simulation and dynamic control of solar assisted ground source heat pump to provide heating load and DHW," Appl. Therm. Eng., vol. 
129, pp. 127-144, 2018.

785

786

787

788

789

790

791

792

793

794

795

796

797

798

799

[34] F. Reda, N. Arcuri, P. Loiacono, and D. Mazzeo, "Energy assessment of solar technologies coupled with a ground source heat pump system for residential energy supply in Southern European climates," Energy, vol. 91, pp. 294-305, 2015.

[35] Q. Si, M. Okumiya, and X. Zhang, "Performance evaluation and optimization of a novel solarground source heat pump system," Energy Build., vol. 70, pp. 237-245, 2014.

[36] E. Wang, A. S. Fung, C. Qi, and W. H. Leong, "Performance prediction of a hybrid solar ground-source heat pump system," Energy Build., vol. 47, pp. 600-611, 2012.

[37] M. Dannemand, B. Perers, and S. Furbo, "Performance of a demonstration solar PVT assisted heat pump system with cold buffer storage and domestic hot water storage tanks," Energy Build., vol. 188-189, pp. 46-57, Apr. 2019.

[38] Department of Civil Engineering; Technical University of Denmark, "DTU Climate Station." .

[39] M. Stegmann, E. Bertram, G. Rockendorf, and S. Janßen, "Model of an unglazed photovoltaic thermal collector based on standard test procedures," Proc. ISES Sol. World Congr. 2011, pp. 252-260, 2011. 


\section{Dear Editor,}

Thank all of you for all the professional comments on our manuscript (ECM-D-19-07045). We address all the comments carefully and make corrections based on the comments. The comments are very important to improve our manuscript. The detailed point-by-point response are listed below. All the changes in the revised version were highlighted with Track Changes.

\section{Editor:}

Avoid using abbreviations and acronyms in title, abstract, headings and highlights.

Reply: These have been double-checked. Thanks. 
1 Simulation and optimization of a hybrid unglazed solar photovoltaic-thermal collector and heat pump system with two storage tanks

5 Mark Dannemand ${ }^{1}$, loannis Sifnaios ${ }^{1}$, Zhiyong Tian $^{2,1^{*}}$, Simon Furbo ${ }^{1}$

1 DTU Civil Engineering, Technical University of Denmark, Brovej, Building 118, DK-2800, Kgs. Lyngby, Denmark

2 Department of Civil and Environmental Engineering, Norwegian University of Science and Technology, Trondheim, Norway

Corresponding author: markd@byg.dtu.dk (Mark Dannemand), zhiyong.tian@ntnu.no (Zhiyong Tian), tianzy0913@163.com(Zhiyong Tian).

\section{Abstract}

Solar thermal energy systems combined with heat pumps are becoming popular solutions for covering space heating and domestic hot water demand in European Union households. There is a great potential for developing high performing systems by combining components in systems in new ways. This study focuses on the performance of a system consisting of heat pump, photovoltaicthermal-(PVT) solar collector and two storage tanks. This system is proposed to potentially have better performance compared to air-to-liquid heat pump system while being less costly compared to a liquid-to-liquid heat pump system with ground sourced heat exchanger. The system was set up at the Technical University of Denmark in 2017, for providing domestic hot water. A simulation model of the system was created in the transient simulation software_TRNSYS-and the data from the experiment were used for its validation. The modulating heat pump was modelled via a function applied to the scale factor and the thermal mass of the heat pump was taken into account be including additional pipes around the heat pump. The performance of the system was assessed using selected kKey pferformance ilndicators. A parametric analysis was performed identifying component sizes that improved the system's performance. The improved system produced 55\% more electricity, had $23 \%$ lower electric consumption and wasted $11 \%$ less heat by minimizing heat losses compared to the demonstration system. The improved system had a solar thermal fraction of 0.58 , a solar electrical fraction of 1.51 and a renewable energy fraction of 0.75 . The system was however oversized compared to the load applied to the system as it was built to cover only a domestic hot water demand. For the system to be economically attractive it must cover a larger load.

Keywords: Solar-assisted heat pump, TRNSYS, buffer tank, domestic hot water tank, photovoltaicthermal collector, heat storage

\section{Nomenclature}

Q $\quad$ Thermal energy produced by the photovoltaic-thermal collectorPVT collector [kWh] 
$39 \mathrm{Q}_{\mathrm{HS}}$

$40 \mathrm{Q}_{\text {sup,HS }}$

$41 \mathrm{Q}_{\text {primary,HP }}$

$42 \mid Q_{\text {PVT,DHW }}$

43 [kWh]

$44 \mid E_{\mathrm{PVT}}$

$45 \quad \mathrm{E}_{\mathrm{HS}}$

$46 \quad \mathrm{f}_{\text {sol,th }}$

$47 \quad f_{\text {sol,el }}$

$48 \quad f_{\text {ren }}$

$49 \quad f_{\text {ISPF }}$

50

51

52

53

54

Thermal energy produced by the heating system (tapped energy) [kWh]

Thermal energy supplied to the domestic hot water tank and heat pump [kWh]

Thermal energy supplied to the primary (source) side of the heat pump [kWh]

Thermal energy supplied by the PVF_photovoltaic-thermal collector to the DHW tank

Electrical energy produced by the PVF collector photovoltaic-thermal collector [kWh] Electrical energy consumed by the heating system [kWh]

Solar thermal fraction [-]

Solar electrical fraction [-]

Net renewable energy factor [-]

Inverse system seasonal performance factor [-]

\section{Abbreviations}

$\begin{array}{ll}\text { DHW } & \text { Domestic Hot Water } \\ \text { PVT } & \text { Photovoltaic-Thermal } \\ \text { ISPF } & \text { Inverse Seasonal Performance Factor } \\ \text { HS } & \text { Heating system, referring to the heat pump and domestic hot water tank } \\ \text { SAHP } & \text { Solar Assisted Heat Pump } \\ \text { KPI } & \text { Key Performance Indicator } \\ \text { WISC } & \text { Wind and Infrared Sensitive Collector } \\ \text { COP } & \text { coefficient of performance }\end{array}$

\section{Introduction}

Space heating and hot water consumption accounts for $79 \%$ of the total final energy use in EU households. In 2018, approximately $84 \%$ of heating and cooling was generated from fossil fuels while only $16 \%$ is generated from renewable sources [1]. In order to fulfil EU's climate and energy goals, the heating and cooling sector must reduce its energy consumption and cut its use of fossil fuels significantly [1]. Solar thermal energy systems combined with heat pumps have become more and more popular options in order to increase the renewable energy share for space heating and domestic hot water systems [2]. Currently, products for combining solar thermal collectors and photovoltaic (PV) panels into one hybrid photovoltaic-thermal (PVT) collector are being developed across the industry. Utilizing PVT collectors allows potentially for developing more efficient solar heating systems when the PVT collectors are combined with heat pumps and storage tanks.

\subsection{Literature study}

The International Energy Agency (IEA) Solar Heating and Cooling Programme (SHC) Task 44/ Heat Pump Programme (HPP) Annex 38 "Solar and heat pumps system" operated from 2010 to 2013. It focused on the assessment of performances and relevance of combined systems using solar thermal collectors and heat pumps, to provide common definition of performances of such systems and to contribute to successful market penetration of these new systems [3]. IEA-SHC Task 60 "Application of PVT Collectors and New Solutions in heating, ventilation and air-conditioning (HVAC) Systems" from January 2018 - December 2020 has been initialed to further develop PVT collectors in the application of HVAC systems [4]. 
Many research projects on solar assisted heat pump (SAHP) systems have been carried out. Bellos et al. [5] made an energetic and financial evaluation of SAHP systems, and found that the most economically attractive system design depended on the electricity price, concluding that, for high electricity prices, the SAHP system with PVT and a liquid based heat pump was the best solution. Rad et al. did a feasibility study of combined solar thermal and ground source heat pump systems [6]. It was found that the net present value of the proposed hybrid system based on the 20 -year life-cycle cost analysis was estimated to be in a range of 3.7\%-7.6\% (or $\$ 1500$ to $\$ 3430$ Canadian dollar) lower than the conventional ground sourced heat pump (GSHP)system depending on the drilling cost. Buonomano et al. [7] assessed the energy and economic performance of a Building Integrated flatplate Photovoltaic Thermal (BIPVT) system for a residential application. The case study showed that the payback period varied from 11 years for South European weather zones to 20 years for North European zones. Fine et al. [8] did a detailed model of a PVT domestic hot water (DHW) system with a cascade heat pump and one storage tank. They found that the system with the cascade heat pump performed better than a PVT heat pump system with a single heat pump or a system with evacuated tube collectors for selected climates in USA and Canada. Busato et al. did a study on which source for the heat pump was the most favorable including ground source heat exchanger and solar collectors [9]. The analysis revealed that the most energy efficient solution both for absorption and compression heat pump based systems was to adopt a multi-source system. Lämmle et al. [10] evaluated the performance of different PVT collector types in four different heating systems using the transient system simulation tool (TRNSYS). They concluded that unglazed PVT collectors achieve high electrical yields, and glazed PVT collector with low-e coatings achieve high thermal yields. Zarrella et al. [11] validated a TRNSYS type based on a novel lumped parameter model for photovoltaic thermal hybrid solar collectors. The contribution of the thermal capacitances of the materials and the heat-carrier fluid of the collector were considered in the type. Calise et al. [12] carried out thermo-economic optimization of a solar-assisted heat pump based on transient simulations and computer design of experiments. A simple pay-back period of about 5 year was achieved based on a case study. Emmi et al. [13] presented a case study on a heat pump coupled with photovoltaic thermal hybrid solar collectors. The solar-air sources system was the best solution for the case study. Jouhara et al. [14] investigated the performance of a combined heat pump solar PVT system and its potential in district heating applications. Solar fraction from $60 \%$ to $100 \%$ was achieved in different days depending on the solar radiation. Dupeyrat et al. [15] studied the thermal and electrical performances of PVT solar hot water systems. They confirmed that PVT collectors in the building envelop can be more advantageous than standard PV and solar thermal components considering the exergy and the primary energy saving. Gürlich et al. [16] investigated the performance of photovoltaic-thermal hybrid collectors for direct regeneration in a European building retrofit case study. They showed that PVT collectors used for heat (primary DHW) and electricity offer approximately $6-7 \%$ higher exergetic efficiency than thermal and PV collectors equally sharing the available surface area. Chen et al. [17] did the performance analysis and multi-objective optimization of a hybrid PVT collector for domestic hot water application. The optimal value of tank volume on Pareto frontier showed an equally scattering distribution between $99.5 \mathrm{~L}$ and $218.6 \mathrm{~L}$ for a $2 \mathrm{~m}^{2}$ glazed PVT collector. Li et al. [18] carried out experimental performance analysis on a directexpansion solar-assisted heat pump water heater. They found that the small system with lower capital cost and smaller collector/evaporator area has the advantage to integrate it with building roof. Deng et al. [19] did the simulation and optimization study on a solar space heating system combined with a low temperature heat pump for single family rural residential houses in Beijing. It is further found that the equivalent solar heat price per kWh was too high under the current solar market cost price and collector technology. 
Sakellariou et al. [20] conducted a sensitivity analyses on a PVT based solar assisted ground source heat pump system using TRNSYS simulation software. It was found that the storage capacity and the plate heat exchanger's effectiveness, contribute the most to the system's and heat productivity of PVT. Aldubyan et al. [21] reported the evaluation of the short and long-term electrical performance of a unglazed PVT system coupled with borehole thermal energy storage in two extreme climate zones in the United States. Significant improvements in PVT cell efficiency in the system without a ground-coupled heat pump compared with conventional PV panels was found. Jonas et al. [22] did a simulation study using TRNSYS of a SAHP system with a borehole ground storage and compared it to other types of systems. They showed that the seasonal performance factor of parallel solar thermal and ground source heat pump systems was between 0.5-1.1 (Strasbourg) and 1.0-2.0 (Helsinki) higher than the seasonal performance factor of parallel solar thermal and air source heat pump systems with the same solar collector area. Li et al. [23] also used TRNSYS to study a SAHP system. It was concluded that the properly designed solar thermal heat pump heating system can operate effectively and reduce tremendous energy consumption compared with the traditional heating system used in cold climate buildings. Xi et al. [24] introduced in their study a ground coupled SAHP system for space heating and DHW. They optimized the system design with TRNSYS and presented its performance for operating in Beijing. Chen and Yang [25] presented a TRNSYS simulation of a SAHP system with ground coupled heat exchanger to find an optimal design for the north China area. The annual total heat extraction plus $75 \%$ of the hot water requirement could be provided by solar energy in the optimized design. Poppi et al. [26] studied different SAHP combined systems, and found that the type and size of the heat pump had a large impact on the electricity consumption required to cover the heat demands of the selected cases. In another study, Poppi et al. [27] analyzed the economic impact of changing the components in SAHP systems, and found that the optimal solution depended on the boundary conditions such as heat demands, climatic conditions and electricity price. Sterling and Collins [28] performed a feasibility analysis of different SAHP systems and used TRNSYS for assessing their performances. It was found that the electrical consumption and operating cost were the lowest with indirect-style solar assisted heat pump. Tzivanidis et al. [29] made an energetic and financial evaluation of a SAHP system comparing it to two other heating systems focusing on the climate of Athens, Greece. They found that the SAHP system had the best energetic performance but not the lowest net present value with the stated electricity prices. Girard et al. [30] showed that the COP of the ground source heat pump system was increased by adding solar collectors. The payback periods of solar-assisted ground-source heatpumps are between 8.5 and 23 years depending on location. Kjellsson et al. [31] did a TRNSYS simulation on solar collectors and ground-source heat pumps in Sweden. They reported that COP values obtained during periods with favorable operational conditions was misleading if the overall annual system performance (SPF) was not mentioned in the same context. Pärisch et al. [32] did investigations and model validation of a ground-coupled heat pump for the combination with solar collectors. It was shown that rising source temperatures did only significantly increase the coefficient of performance (COP), if the source temperature was below $10-20{ }^{\circ} \mathrm{C}$, depending on the temperature lift between source and sink. Razavi et al. [33] designed a solar assisted GSHP system to provide heating load and domestic hot water for a house located in Zahedan, Iran. Energy consumption of solar assisted GSHP system was $8.7 \%$ lower than GSHP standalone system Rada et al. [34] did energy assessment of solar technologies coupled with a ground source heat pump system for residential energy supply in Southern European climates. They found that PV and solar thermal systems allowed high energy savings compared in Italy. Si et al. [35] compared the performance of two different solar-ground source heat pump systems. It was suggested to operate the system without heat pump in transition seasons. Wang et al. [36] also studied the performance of a hybrid
Field Code Changed

Formatted: English (United States)

Formatted: English (United States) 
ground source SAHP system . They reported that the control strategy of load circulation pump could result in energy saving.

\subsection{Scope}

This study focuses on the performance of a system consisting of a heat pump, a PVT collector and two storage tanks. An experimental setup with an unglazed PVT collector, liquid-to-liquid heat pump, a domestic hot water (DHW) tank and a buffer tank has been set up at the Technical University of Denmark in 2017. The load for the system was automated hot water tapping. The thermal output of the unglazed PVT collector was used to charge both tanks on sunny days. Also, the unglazed PVT collector was used as a heat exchanger, to extract low temperature heat from the ambient environment when there was limited or no solar radiation available. This was used to increase the water temperature in the buffer tanks which was the source of the heat pump. This type of system not only potentially allows for having better performing systems compared to air-toliquid heat pump systems, but also has lower cost compared to liquid-to-liquid heat pump systems with a ground sourced heat exchanger. The performance of the demonstration system has been analyzed by Dannemand et al. [37]. In the present study, a TRNSYS model was built and validated with the measurements and the yearly performance of the system was simulated. Furthermore, the sizing of various components was varied in a parametric study. It was found that improvements on the demonstration system were possible, in order to enhance its performance.

To the best of the authors' knowledge, only limited publications on systems consisting of heat pump, PVT collector and two storage tanks have been made. No studies were found on modeling and validation of such systems using TRNSYS in the literature.

\section{Methods}

In this section the system setup under investigation is described, as well as the TRNSYS model created for simulating its operation. Lastly, the Key Performance Indicators (KPI) used for assessing the system performance are presented.

\subsection{Experimental set up}

The PVT assisted heat pump system consisted of at $3.1 \mathrm{~m}^{2}$ uninsulated uncovered, wind and infrared sensitive collector (WISC) prototype PVT collector manufactured by Racell Technologies. Monocrystalline solar cells covered $2.58 \mathrm{~m}^{2}$ of the absorber area. The PVT collector was installed with a $45^{\circ}$ tilt facing south, raised approximately $10 \mathrm{~cm}$ above roof, allowing air to pass freely on the backside. The thermal absorber of PVT collector was connected to a heat exchanger spiral in the bottom of a 160 liters domestic hot water (DHW) storage tank. Further, the solar collector loop was connected to a 200 liters buffer storage tank with a direct inlet to the top of the tank. A $40 \%$ propylene glycol/water mixture was used to fill the solar collector loop and buffer storage.

The DHW tank was also heated by a heat pump, via a heat exchanger spiral in the top of the tank. When heat from the solar collector was insufficient to maintain the required temperature level in the top of the DHW tank, the heat pump was activated. The heat pump used was a NIBE F1155-6, with a frequency speed regulated compressor. The supplier specified thermal power output at $0 / 35$ ${ }^{\circ} \mathrm{C}\left(0{ }^{\circ} \mathrm{C}\right.$ at the inlet on the source side of the heat pump, $35{ }^{\circ} \mathrm{C}$ at the outlet on the load side of the 
heat pump) was $3.15 \mathrm{~kW}$ (thermal) with an electrical power consumption of $0.67 \mathrm{~kW}$ (electrical) at $50 \mathrm{~Hz}$. The source side of the heat pump was connected to the buffer storage tank.

The pipes between the heat pump and the DHW and buffer storage tanks were each approximately 6 meters long. The pipes between the DHW tank and the PVT panel were each 24 meters long and approximately half the pipe was located indoors and half outdoors. In order to investigate the performance of the system, tapping of domestic hot water from the DHW tank occurred three times per day with an energy draw off of $4.5 \mathrm{kWh}$ per day. That corresponded to 110-145 liters of water per day, depending on the temperature difference between the cold and hot water. The tapping was realized via an automated system at the test facilities. Figure 1Figure 1 shows a schematic of the system under investigation.

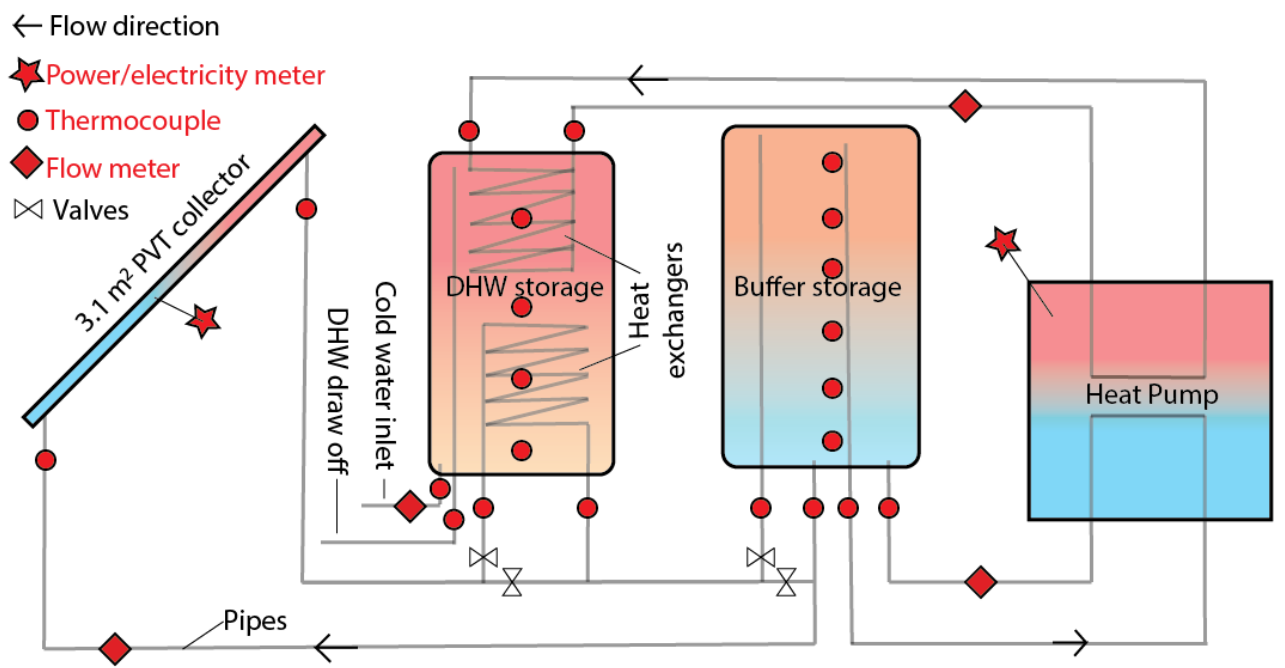

Figure 1: Schematic of the investigated PVT system at the Technical University of Denmark with measurement locations

\subsubsection{Measurements}

Temperatures, flow rates and electricity production/consumption were measured at the locations indicated in Figure 1Figure 1. Measurements from August 7 to December 21, 2017 were used for validating the TRNSYS model.

A National Instrument CRIO with 9214 and 9403 cards were used for the data logging. Absolute temperatures of the fluid in the system were measured with thermocouples type $T$ (uncertainty less than $\pm 0.42{ }^{\circ} \mathrm{C}$ in the applied temperature range) at the locations indicated in Figure 1Figure 1 . The ambient temperature was likewise measured with a thermocouple type T. A five junction thermopile (uncertainty less than $\pm 0.15^{\circ} \mathrm{C}$ ) were used to measure the temperature difference between the inlet and outlet of the PVT collector. Kamstrup and Brunata flow meters (class 2 sensor, accuracy less than $2 \%$ after calibration) were used to measure the flow rates in the loops indicated in Figure 1Figure 1. CMP11 Kipp \& Zonen pyranometers (inaccuracy less than 2\%) were used to measure the total and diffuse irradiances in the same plane as the collector. The infrared irradiation on the tilted collector were measured using a CG1 pyrgeometer from Kipp \& Zonen (accuracy less than $1 \%$ in the application range). Electronic single phase energy meters from Eltako Electronics (accuracy less than $1 \%)$ were used to measure the electricity consumption of the heat pump and the electricity 
production of the PVT collector. Typical calculated uncertainty of the measured heat output of PVT collector, which is based on measured temperature difference and flow rate, is within 5\%.; Lastly, the wind speed in the collector plane was measured with an ultra-sonic wind speed and direction sensor from Gill (accuracy less than 2\%). It was noticed that the average wind speed in the collector plane was $31 \%$ of the wind speed measured at the DTU Climate Station [38]. Since this percentage was relatively constant, this factor was applied in the TRNSYS yearly simulation for finding the speed in the collector plane.

\subsubsection{Control strategy}

The control strategy applied to the experimental setup was as follows:

- When the temperature in the top of the DHW tank dropped below $42{ }^{\circ} \mathrm{C}$, the heat pump charged the DHW tank until the temperature in the top of the tank reached $50^{\circ} \mathrm{C}$.

- When the temperature at the outlet of the PVT collector was $4{ }^{\circ} \mathrm{C}$ higher than the bottom of the buffer storage, the collector loop pump started. The solar collector loop pump stopped when the temperature difference dropped below $0{ }^{\circ} \mathrm{C}$.

- When the temperature in the top of the buffer tank was below $25{ }^{\circ} \mathrm{C}$, the flow in the collector loop was directed into the top of the buffer storage tank. If the temperature in the top of the buffer tank was higher than $25^{\circ} \mathrm{C}$, the tank was bypassed because the maximum allowed inlet temperature to the source side of the heat pump was $30^{\circ} \mathrm{C}$.

- The flow in the collector loop was directed through the heat exchanger in the lower part of the DHW tank when the temperature at the outlet of the PVT collector was $4{ }^{\circ} \mathrm{C}$ higher than the bottom of the DHW tank. The DHW tank was bypassed when the temperature difference dropped below $0{ }^{\circ} \mathrm{C}$.

The used control strategy in the demonstration installation, although simple and easy to implement, may not be optimal for the system. There were scenarios when the collector loop pump was in operation while both storage tanks were bypassed.

\subsection{Simulation model and validation}

The software selected for assessing the system performance was the simulation software TRNSYS, as it is a flexible graphically based software able to model transient systems, widely used by the energy simulation community.

\subsubsection{Part models}

Initially, models of the PVT collector, the heat pump and the tanks were created to validate the individual parts of the system, before they were combined to the full model of the PVT system.

\subsubsection{Photovoltaic-thermal collector model}

The prototype PVT collector had not been characterized in detail before the PVT system was set in operation. Therefore, a model only focusing on the collector was initially built in order to identify the collector's coefficients. TRNSYS "Type 203: PVT collector" developed by Institut für Solarenergieforschung GmbH (ISFH) [39] was chosen for the PVT collector. The thermal and electrical outputs of the model, calculated using the measured weather conditions, inlet temperatures and flows, were compared to the measured output of the PVT prototype. The collector parameters in the model were adjusted to give a good fit between measurements and calculations. This was done 
considering the characteristics of similar collectors, but also the installation, in order to have reasonable parameters for the PVT collector. The values listed in Table 1 were used for the parameters in the PVT collector model. The default values of Type 203 were used for parameters not listed in Table 1Fable 1.

\section{Table 1: Parameters in Type 203 used for the PVT collector model.}

\begin{tabular}{llll}
\hline Parameter & Description & Value & Unit \\
\hline 8 & Conversion factor (thermal) & 0.66 & - \\
9 & Wind dependent conversion factor & 0.01 & $\mathrm{~s} / \mathrm{m}$ \\
10 & Heat loss coefficient & 16 & $\mathrm{~W} /\left(\mathrm{m}^{2} \cdot{ }^{\circ} \mathrm{C}\right)$ \\
11 & Wind dependent heat loss coefficient & 3.5 & $\mathrm{~J} /\left(\mathrm{m}^{3} \cdot{ }^{\circ} \mathrm{C}\right)$ \\
14 & Heat capacity & 20 & $\mathrm{~kJ} /\left(\mathrm{m}^{2} \cdot{ }^{\circ} \mathrm{C}\right)$ \\
23 & PVT module electrical efficiency at reference condition* & 0.098 & - \\
28 & Coefficient for temperature dependent electrical efficiency & -0.4 & $\% /{ }^{\circ} \mathrm{C}$ \\
\hline
\end{tabular}

${ }^{*}$ The relatively low electrical efficiency of the PV part of the PVT collector (0.098) reflects that only part (83\%) of the prototype PVT collector was covered with solar cells. Also the losses in the inverter is included in this value as the electrical output from the PVT collector was measured after the inverter.

\subsubsection{Heat pump model}

The heat pump operation including the pipe loops on the source and load side, was simulated in TRNSYS. The electrical power consumption, temperatures and thermal power in the pipe loops were used to calibrate the model in order to fit the measurements. TRNSYS "Type 927: Normalized waterto-water heat pump" was used for the heat pump and "Type 604: Bi-directional, node pipe with wall and insulation mass" was used for the $4 \times 6$ meter pipes between the heat pump and the two tanks in order to include the thermal mass and fluid in the pipes. A performance map from the heat pump supplier was used to calculate the performance of the heat pump.

From the conducted experiments, it was observed that the heat pump operated for very short periods throughout the day. For this reason, a significant amount of heat was lost to the ambient due to the thermal capacity of the heat pump. However, none of the existing TRNSYS heat pump components was able to take into account this effect. It was also noticed that, after the heat pump operation, heat was left in the pipes causing significant heat losses to the ambient. For these reasons, it was decided to include in the TRNSYS model additional $19 \mathrm{~m}$ of pipes to the load loop and $2 \mathrm{~m}$ to the source loop, to compensate for the heat pump thermal mass. Pipe insulation thickness and thermal conductivity were implemented considering the thermal bridges in the physical installation.

The physical heat pump used a frequency inverter in order to modulate the heat pump's compressor operation for optimal performance. The electrical power consumption of the heat pump varied throughout the measurement period, having higher electrical consumption for colder inlet temperatures on the source side of the heat pump. Modulating heat pump technology is currently not included in any of the standard TRNSYS heat pump components. For this reason, a function using the source temperature entering the heat pump was included in the heat pump model to control the heat pump's scale factor. This way, the thermal output and electrical consumption of the heat pump 
could be increased or decreased according to the source temperature, simulating the modulating power operation of the heat pump. In this way the electrical consumption of the heat pump varied with the operating conditions in a similar way as it did in the experimental setup. Lastly, in order to include the standby electricity consumption of the heat pump in TRNSYS, a constant $19 \mathrm{~W}$ were added to the heat pump electrical power consumption.

\subsubsection{Buffer and domestic hot water tank models}

Both buffer and DHW tanks were simulated with TRNSYS "Type 534: Vertically cylindrical storage tanks with optional immersed heat exchangers". Models focusing only on the temperature development inside the tanks in standby periods were used to adjust the heat loss coefficient and the downwards thermal conductivity in the tanks, so that the measurement and simulation results were in good agreement. The buffer tank had a volume of 200 liters and height of $1.4 \mathrm{~m}$ and the DHW tank had a volume of 160 liters and a height of $1.2 \mathrm{~m}$. The geometry and design of the tanks in the model were set to match the actual designs.

The measurements indicated some degree of thermosiphon in the loop between the buffer tank and the heat pump, in periods where there was no flow in the loop. The thermosiphon appeared to go the opposite direction of the normal flow in the loop. When the heat pump operation stopped, the temperature sensor at the inlet of the buffer tank from the heat pump (source side) located in a pipe approximately $40 \mathrm{~cm}$ below the tank, remained at a temperature level similar to the bottom of the buffer tank. This indicated that fluid flowed down from the tank through this pipe. On the contrary, the temperature sensor at the outlet of the tank (to the heat pump source), remained above the buffer tank and ambient air temperature suggesting that some heat was transferred via the pipes into the tank. This suggests that thermosiphon occurred after the heat pump stopped, indicating that leftover heat from the heat pump or heat from the standby crankcase heater was transferred to the upper part of the buffer tank. Without thermosiphon the temperature sensors of the inlet and outlet measured in the pipes close to the tank would have stabilized close to ambient indoor temperature. A miscellaneous heat gain to the upper part of the tank model and high heat loss coefficients were added to the buffer tank model to compensate for thermosiphon.

\subsubsection{Full model}

The settings for the part models of the individual components were combined into a full PVT system model. The system was built up using the components and types listed in Table 2Fable 2 . Figure 2 Figure 2 shows the main components in the TRNSYS environment.

\begin{tabular}{lll} 
& Table 2: Components and types used in the TRNSYS model \\
\hline Component & Type number & Type name \\
\hline PVT collector & 203 & $\begin{array}{l}\text { PVT collector } \\
\text { Pipes }\end{array}$ \\
Heat pump & 604 & $\begin{array}{l}\text { Bi-directional node pipe with wall and insulation } \\
\text { mass }\end{array}$ \\
DHW / buffer storage tank & 534 & $\begin{array}{l}\text { Normalized water-to-water heat pump } \\
\text { Vertically cylindrical storage tanks with optional } \\
\text { immersed heat exchangers }\end{array}$ \\
Controls & 911 & Differential controller with lockouts \\
Load profile & 14 & Forcing function - general \\
Flow diverter / T-piece & 11 & Flow diverter - other fluids \\
\hline
\end{tabular}


A DHW tapping pattern matching the pattern in the demonstration system was applied to the model. The measured cold water temperature was implemented and tap flow rate was adjusted to fit the measured tapped energy quantities to the simulated.

The control strategy applied for the physical system as described in section 2.1.2 Control strategy, was implemented in the TRNSYS model by four individual Type 911 controllers. The absorber temperature simulated by the Type 203 was used at the upper temperature limit for hysteresis control of the pump for the solar collector loop. The flow in the solar collector loop was set to 3 liters per minute.

The pipes in the solar collector loop were divided into indoor and outdoor parts and the insulation was implemented in the simulation model according to the actual dimensions and conditions.

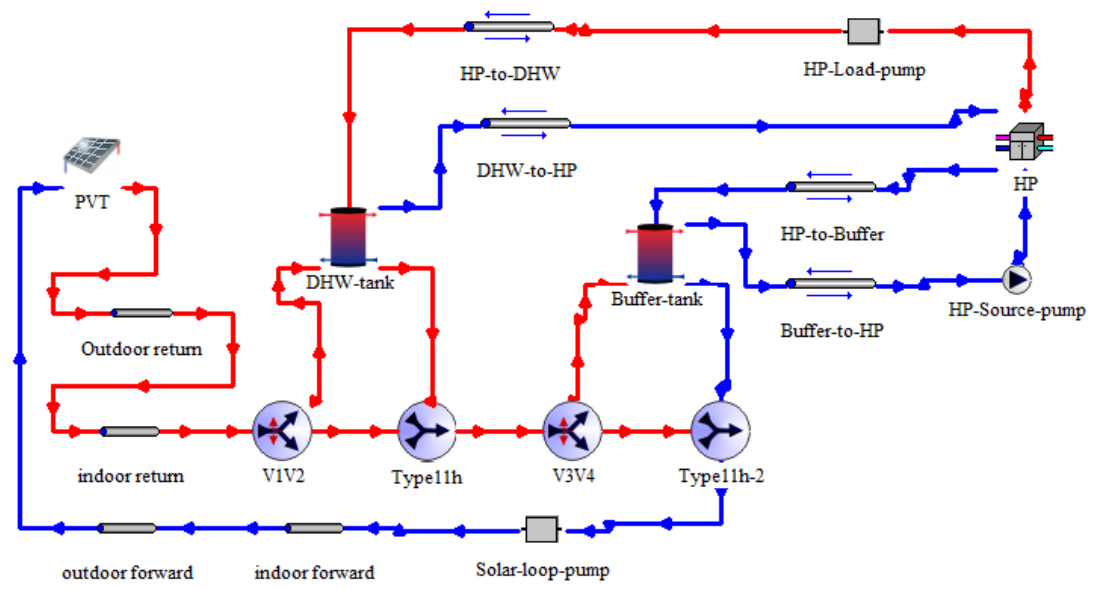

Figure 2: Main components of the PVT heat pump dual tank model in TRNSYS.

\subsubsection{Yearly simulation}

In order to evaluate the performance of the system throughout the year in Danish climatic conditions, a new simulation was performed using the validated TRNSYS model. The difference between the validated model and yearly simulation was that data from measurements were not fed to the model, but reference conditions were used instead. The system simulated supplied domestic hot water at $50{ }^{\circ} \mathrm{C}$ with a constant cold water temperature of $10{ }^{\circ} \mathrm{C}$, without supplying water for space heating. Since the system was assumed to be placed indoors, it was exposed to a constant ambient temperature throughout the year of $20{ }^{\circ} \mathrm{C}$. The tapping of domestic hot water occurred three times per day; namely at $7 \mathrm{am}, 12 \mathrm{pm}$ and $7 \mathrm{pm}$. The total daily need for domestic hot water was 100 liters, amount that corresponds to an average single family house in Denmark. Regarding weather data, the reference weather file available in TRNSYS from Meteonorm library named "DKKobenhavn-Taastrup-61800", was used for the simulation.

\subsubsection{Parameter variations}

Parameter variation for various components (PVT collector area, tank volumes) of the system were performed in order to identify their effect on the system's performance. Afterwards, some scenarios where the existing system was improved regarding insulation, pipe length and heat exchanger dimensions were investigated. Finally, an optimized system simulation was conducted where the best performing solutions were combined and compared to the reference system. 


\subsection{Key pRerformance itndicators}

In order to assess the performance of the system under investigation, some key performance indicators (KPIs) were calculated, which give information about the thermal and electrical performance of the system. The indicators used were suggested by the International Energy Agency - Solar Heating \& Cooling Programme - Task 60 (IEA-SHC-Task 60) [4] and are presented in equations $1-5$. The term heating system (HS) is used for referring to the entire system under investigation except from the PVT panel.

- Solar thermal fraction:

$$
f_{\text {sol,th }}=\frac{Q_{P V T}}{Q_{\text {sup }, H S}}
$$

Where:

$$
Q_{\text {sup }, H S}=Q_{\text {primary }, H P}+Q_{P V T, D H W}
$$

The solar thermal fraction calculates the amount of thermal energy produced by the PVT panel divided by the thermal energy supplied to the heating system.

- Solar electrical fraction:

$$
f_{\text {sol,el }}=\frac{E_{P V T}}{E_{H S}}
$$

The solar electrical fraction calculates the amount of electrical energy produced by the PVT divided by the electrical energy used by the heating system.

- Net renewable energy fraction:

$$
f_{\text {ren }}=\frac{Q_{P V T}+E_{P V T}}{Q_{\text {sup }, H S}+E_{H S}}
$$

The net renewable energy fraction calculates the amount of renewable energy made available (sum of thermal and electrical energy produced by the PVT collector) divided by the total amount of energy used by the heating system.

- Inverse system seasonal performance factor (ISPF):

$$
f_{I S P F}=\frac{E_{H S}-E_{P V T}}{Q_{H S}}
$$

The inverse system performance factor calculates the amount of electricity taken from the grid (if positive) or the amount of electricity fed to the grid (if negative). The reason for using the inverse SPF was that, in some of the investigated cases, the generated amount of solar electricity was larger than the demand of the heating system. That gave negative SPF, which had no physical meaning.

\section{Results and ḋiscussion}

Initially, the results from the validation of the simulation model is presented. Afterwards results from simulations over a year is presented via selected KPIs including the parameter variation on components sizes and system improvements. 


\subsection{Validation}

Each component of the system was validated individually. Having specified the particular coefficients of each component, the full model was also validated.

\subsubsection{Part $\underline{v} \forall a l i d a t i o n$}

The collector loop, the heat pump including the pipe loops to the connected tanks and the two storage tanks were validated separately.

\subsubsection{Photovoltaic-țfhermal collector model validation}

The daily accumulated measured and simulated electrical and thermal output of the PVT collector is displayed in Figure 3Figure 3. The deviation between the measured and calculated energy quantities were less than $1 \%$ over the entire measurement period. On a monthly basis, the deviations were less than $5 \%$, except for the electrical output in the winter period, where the output was very low and the relative deviation therefore was higher.

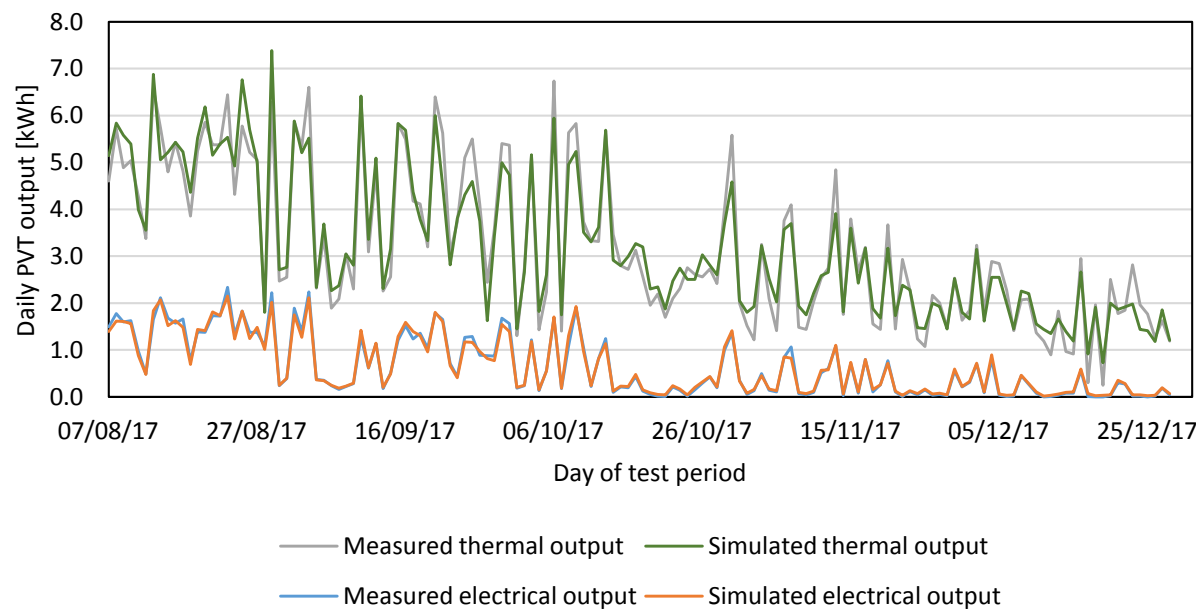

Figure 3: Daily measured and simulated electrical and thermal output of the PVT collector.

\subsubsection{Heat pump}

The measured and simulated electrical consumption and the thermal load output from the heat pump were compared over the test period in Figure 4Figure 4. Over a monthly basis, the deviations between measurement and calculations were less than $4 \%$. 

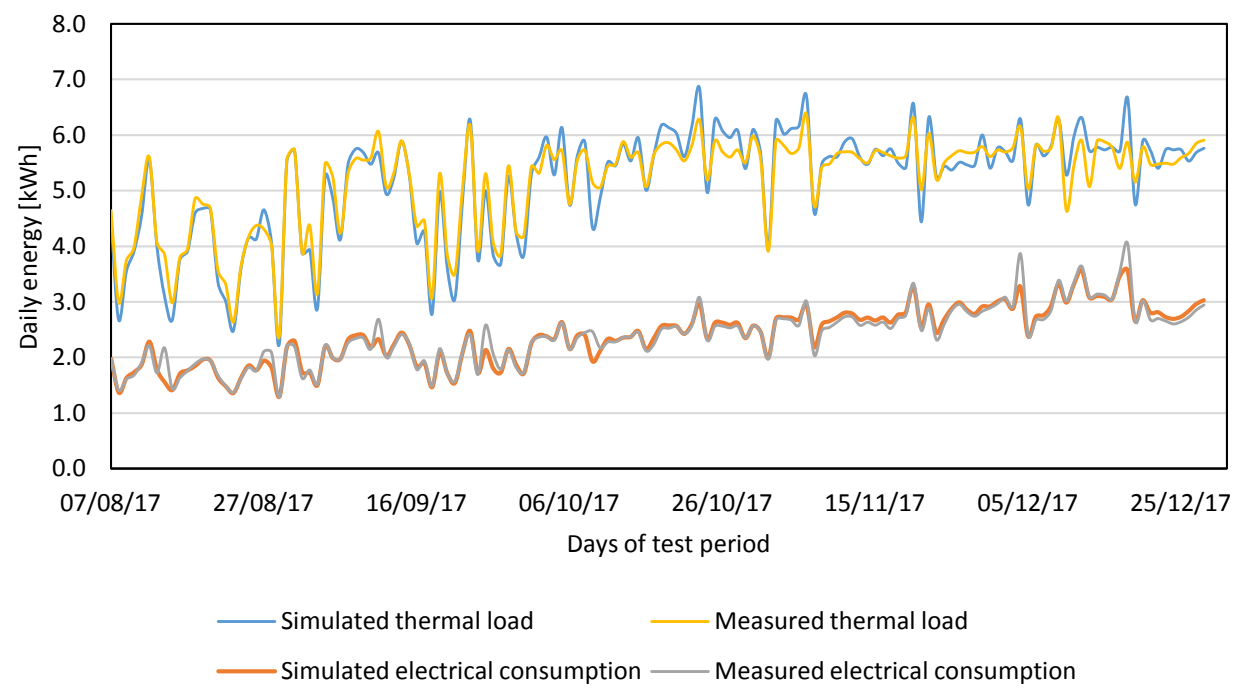

Figure 4: Measured and simulated daily electrical power consumption and thermal load delivered by pipe loop.

\subsubsection{Buffer tank and domestic hot water tank}

Several 7-9 hour periods, where there was no flow though the tanks, were used to match the simulated heat losses from the tanks to the measurement.

The temperature in the buffer tank was typically lower than the indoor temperature and therefore heat was passively supplied to the tank in the standby periods. The heat loss coefficients of the sides, top and bottom were set so that the measurement of the temperature development in the tank matched the simulated. The heat gain from the thermosiphon described in section 2.2.1.3 was included in the heat loss coefficient for the upper tank layer. The heat loss coefficient at the top of the buffer tank was set to $0.8 \mathrm{~W} /{ }^{\circ} \mathrm{C}$, and the nodal edge heat loss coefficient at node 1 to $1.1 \mathrm{~W} /{ }^{\circ} \mathrm{C}$. The total heat loss coefficient for the remaining tank side was set to $2 \mathrm{~W} /{ }^{\circ} \mathrm{C}$ and for the bottom to $1.4 \mathrm{~W} /{ }^{\circ} \mathrm{C}$. A miscellaneous heat gain of $30 \mathrm{~W}$ was added to the upper part of the tank model (node $5)$, to compensate for the passive heat gain from the heat pump due to the thermosiphon in the standby periods. That way the measured temperature development in the tank matched the calculated temperature development in standby periods both in situations where the temperature in the tank was close to the ambient indoor temperature and in cases where the temperature in the buffer tank was significantly lower than the indoor temperature. For the DHW tank the top heat loss coefficient was set to $0.8 \mathrm{~W} /{ }^{\circ} \mathrm{C}$, side to $1.9 \mathrm{~W} /{ }^{\circ} \mathrm{C}$, and the bottom to $0.2 \mathrm{~W} /{ }^{\circ} \mathrm{C}$.

Figure 5 Figure 5 and Figure 6 Figure 6 , show the measured and simulated temperature developments in the top, middle and bottom of the DHW and buffer tanks during a 6 hours standby period. There were minor deviations between the measured and simulated temperatures in the middle of the DHW tank in the first part of the period. 

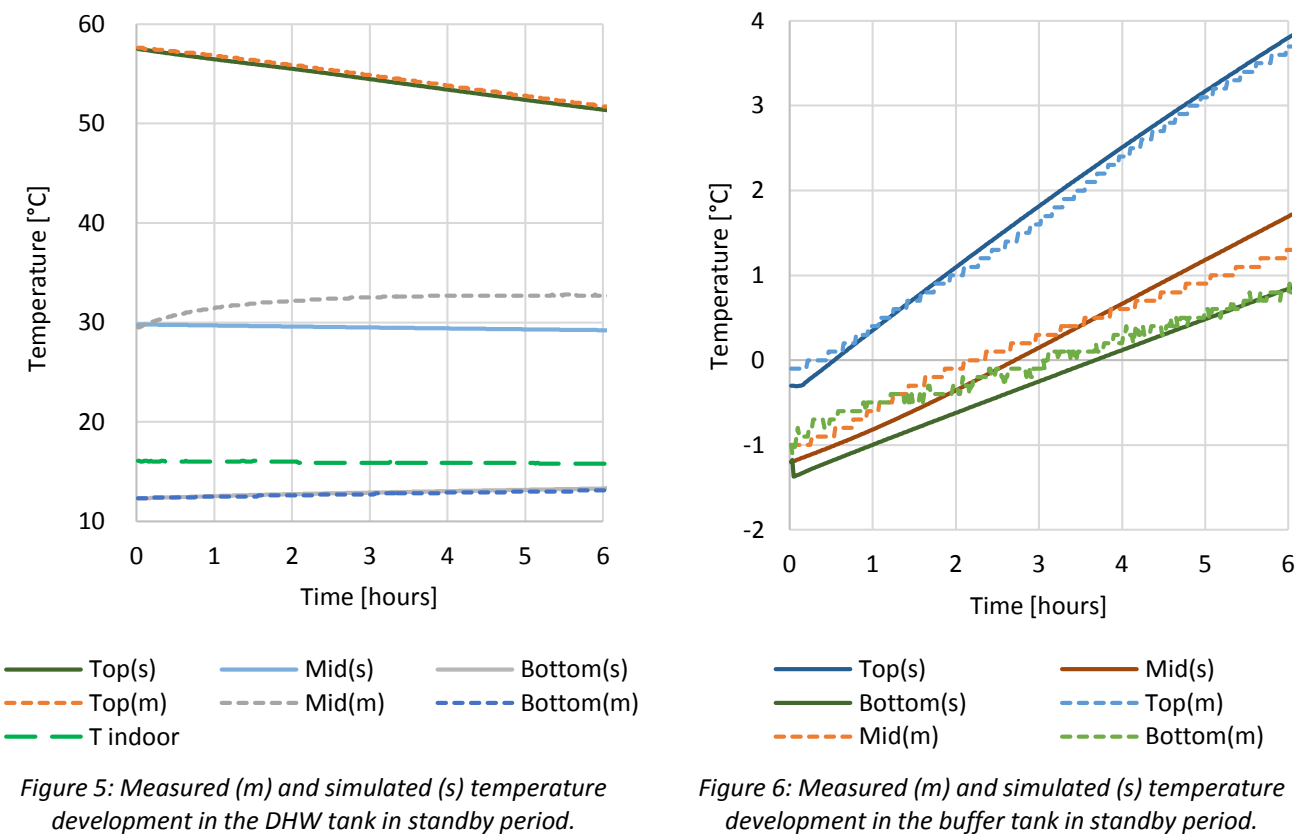

Figure 6: Measured $(m)$ and simulated (s) temperature development in the buffer tank in standby period.

\subsubsection{Full model validation}

The measured and simulated energy transfer at key locations in the system were used to validate the full model against the measurements. Table 3 Fable 3 shows the measured and simulated energy quantities for tapped DHW, thermal and electrical output of the PVT collector, electrical consumption of the heat pump, heat delivered to the DHW tank by the heat pump and heat Formatted: Check spelling and grammar extracted from the buffer storage by the heat pump.

Table 3: Measured (M) and simulated (S) energy quantities in kWh/day for full model validation.

\begin{tabular}{|c|c|c|c|c|c|c|c|c|c|c|c|c|}
\hline \multirow[t]{2}{*}{ Month } & \multicolumn{2}{|c|}{$\begin{array}{c}\text { Thermal } \\
\text { collector } \\
\text { output } \\
\text { [kWh/day] }\end{array}$} & \multicolumn{2}{|c|}{$\begin{array}{c}\text { Tapped } \\
\text { DHW } \\
\text { [kWh/day] }\end{array}$} & \multicolumn{2}{|c|}{$\begin{array}{c}\text { PV electrical } \\
\text { output } \\
{[\mathrm{kWh} / \text { day }]}\end{array}$} & \multicolumn{2}{|c|}{$\begin{array}{l}\text { Heat pump } \\
\text { electrical } \\
\text { consumption } \\
\text { [kWh/day] }\end{array}$} & \multicolumn{2}{|c|}{$\begin{array}{c}\text { Heat } \\
\text { delivered to } \\
\text { DHW by } \\
\text { heat pump } \\
\text { [kWh/day] }\end{array}$} & \multicolumn{2}{|c|}{$\begin{array}{c}\text { Heat } \\
\text { extracted } \\
\text { from buffer } \\
\text { storage by } \\
\text { heat pump } \\
\text { [kWh/day] }\end{array}$} \\
\hline & $M$ & $S$ & $M$ & $S$ & $M$ & $S$ & $M$ & $S$ & $M$ & $S$ & $M$ & $S$ \\
\hline Aug. & 5.16 & 5.16 & 4.3 & 4.52 & 1.52 & 1.53 & 1.74 & 1.84 & 4.04 & 3.96 & 4.4 & 4.64 \\
\hline Sept. & 4 & 3.98 & 4.35 & 4.32 & 0.92 & 0.92 & 2.05 & 2.12 & 4.95 & 4.85 & 5.06 & 5.12 \\
\hline Oct. & 3.29 & 3.27 & 4.33 & 4.52 & 0.57 & 0.55 & 2.38 & 2.31 & 5.19 & 5.47 & 5.49 & 5.26 \\
\hline Nov. & 2.25 & 2.32 & 4.43 & 4.47 & 0.32 & 0.3 & 2.65 & 2.65 & 5.33 & 5.57 & 5.47 & 5.25 \\
\hline Dec. & 1.74 & 1.81 & 4.52 & 4.51 & 0.22 & 0.19 & 3.14 & 2.97 & 5.46 & 5.65 & 5.39 & 5.14 \\
\hline Total & 16.4 & 16.5 & 21.9 & 22.3 & 3.6 & 3.5 & 12.0 & 11.9 & 25.0 & 25.5 & 25.8 & 25.4 \\
\hline
\end{tabular}


Table 4Table 4 illustrates the deviations between the previously mentioned quantities. It can be observed that the deviations between the measured and simulated values were less than $6 \%$ for each period and key location except for the electrical output of the PVT collector in December, similar as in the part collector model.

\begin{tabular}{ccccccc}
\multicolumn{5}{c}{ Table 4: Deviations between the simulated and the measured energy quantities for full model validation. } \\
\hline Month & $\begin{array}{c}\text { Thermal } \\
\text { collector } \\
\text { output }\end{array}$ & $\begin{array}{c}\text { Tapped } \\
\text { DHW }\end{array}$ & $\begin{array}{c}\text { PV } \\
\text { electrical } \\
\text { output }\end{array}$ & $\begin{array}{c}\text { Heat pump } \\
\text { electrical } \\
\text { consumption }\end{array}$ & $\begin{array}{c}\text { Heat } \\
\text { delivered } \\
\text { to DHW by } \\
\text { heat pump }\end{array}$ & $\begin{array}{c}\text { Heat } \\
\text { extracted } \\
\text { from buffer } \\
\text { storage by } \\
\text { heat pump }\end{array}$ \\
\hline Aug. & $0 \%$ & $5 \%$ & $1 \%$ & $5 \%$ & $-2 \%$ & $5 \%$ \\
Sept. & $-1 \%$ & $-1 \%$ & $0 \%$ & $3 \%$ & $-2 \%$ & $1 \%$ \\
Oct. & $-1 \%$ & $4 \%$ & $-3 \%$ & $-3 \%$ & $5 \%$ & $-4 \%$ \\
Nov. & $3 \%$ & $1 \%$ & $-6 \%$ & $0 \%$ & $5 \%$ & $-4 \%$ \\
Dec. & $4 \%$ & $0 \%$ & $-14 \%$ & $-6 \%$ & $3 \%$ & $-5 \%$ \\
Total & $1 \%$ & $2 \%$ & $-1 \%$ & $-1 \%$ & $2 \%$ & $-2 \%$ \\
\hline
\end{tabular}

\subsection{Yearly pRerformance}

The simulated yearly performance of the system is presented. First by showing the effect on the KPIs by varying the component sizes. Followed by the effect of including the system improvements and lastly the performance of the original system is compared to the improved system with selected component sizes.

\subsubsection{Parameter variation results}

In Figure 7Figure 7 to Figure 10Figure 10, selected KPIs are presented for PVT collector size, buffer and DHW storage tank volumes, as well as the results for parameter variation of these components. The existing (reference) system is presented by the orange bar in all figures and its level is also indicated by a dashed black line. Figure 7Figure 7 shows the solar thermal fraction for the system including the parameter variation. 


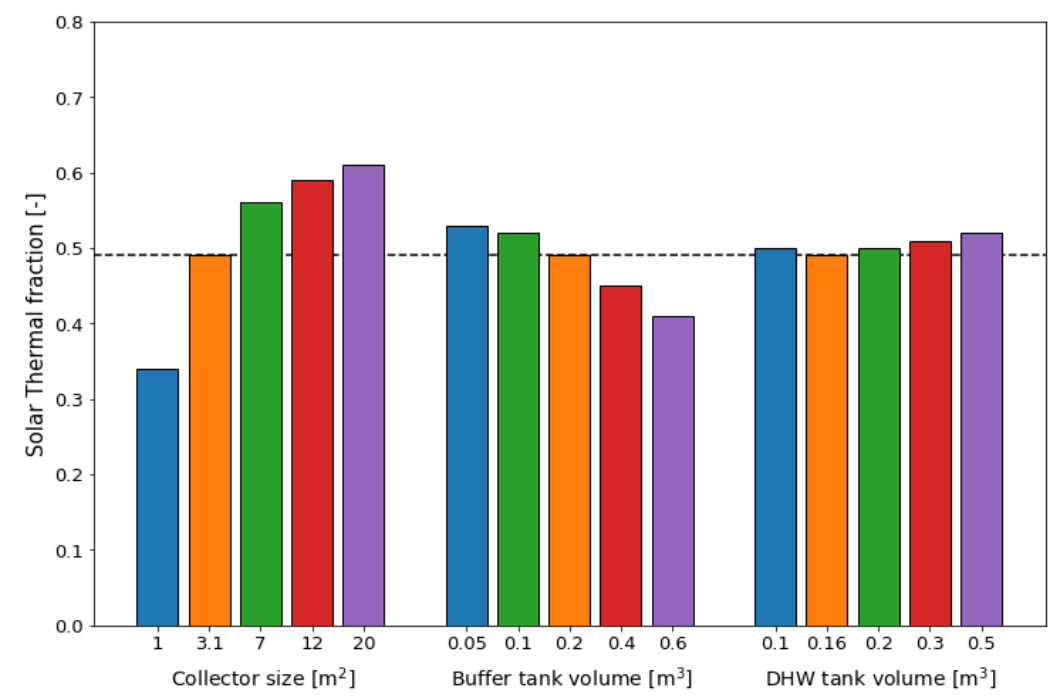

Figure 7: Solar thermal fraction for collector size, buffer and DHW tank volume parametric analysis.

The reference system's solar thermal fraction was 0.49 . In Figure 7Figure 7 , it can be observed that using a larger PVT collector area, the solar thermal fraction of the system can be improved. Calculating the thermal fraction increase over the collector area, a $2 \%$ fraction increase per $\mathrm{m}^{2}$ was found when increasing from 3.1 to $7 \mathrm{~m}^{2}$. A $1 \%$ and $0.5 \%$ fraction increase per $\mathrm{m}^{2}$ was found when increasing the collector area from 7 to 12 and 12 to $20 \mathrm{~m}^{2}$, respectively. This indicates that as the collector area becomes larger less and less of the additional heat produced would be utilized by this system.

The obtained results indicate that the smallest volume of buffer tank tested led to the highest solar thermal fraction. Normally, a larger buffer tank would provide a larger heat source for the heat pump leading to improved performance of the system. In this system though, since the buffer tank was not well insulated, the temperature of the buffer tank was highly influenced by the indoor temperature. For this reason, a smaller tank is heated easier by the indoor temperature compared to a big tank, especially in the winter period where the ability of the PVT collector to heat the tank is limited. When running the simulations for buffer tanks smaller than 200 liters it was noticed that the temperature of the buffer tank could reach very low levels (e.g. up to $-15^{\circ} \mathrm{C}$ ) when the heat pump was in operation. However, in reality, the heat pump has a safety mechanism which shuts down the heat pump when the source temperatures are below $-7{ }^{\circ} \mathrm{C}$ and uses an electrical heater to heat up the DHW tank instead. Since small buffer tanks reached temperature levels lower than $-7{ }^{\circ} \mathrm{C}$, an electrical heater was implemented in the DHW tank to simulate this behavior. The thermal performance of the system remained unchanged with this modification but the electricity consumption of the system was affected.

Regarding the DHW tank, it seems that the solar thermal fraction is barely affected by a change in the tank volume. This however means that a smaller (thus cheaper) tank could be used in the system without affecting its operation and performance.

The results obtained by the simulation and parameter variations suggest that the system under investigation is probably over-dimensioned, since smaller tanks would increase its thermal performance.

Figure 8Figure 8 shows the solar electrical fraction for the system including the parameter variation. 


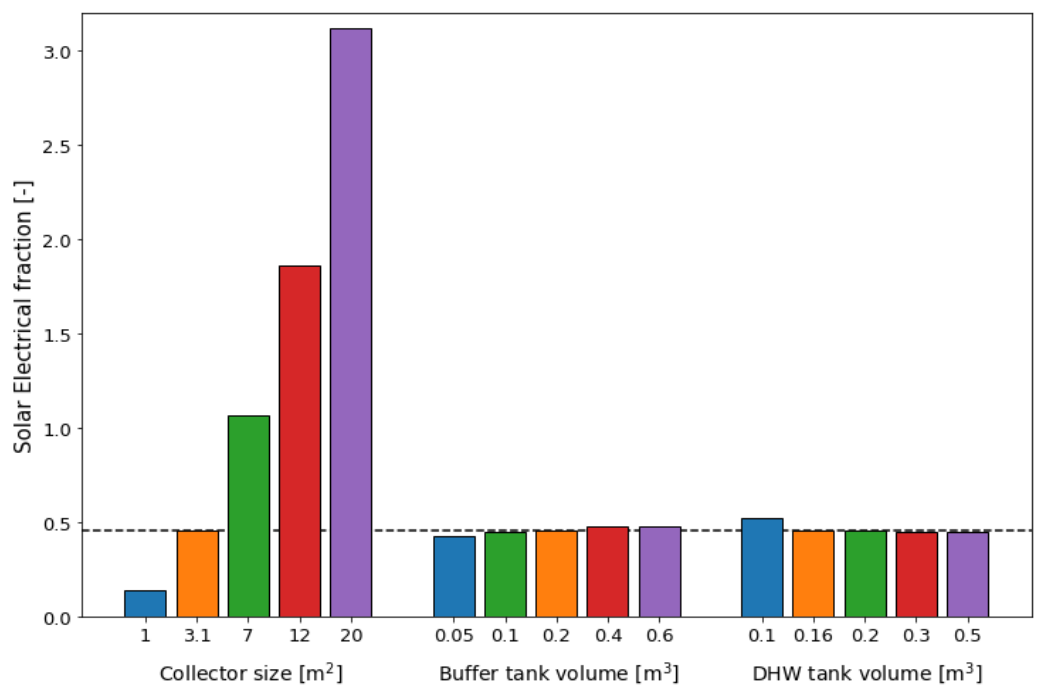

Figure 8: Solar electrical fraction for collector size, buffer and DHW tank volume parametric analysis.

The solar electrical fraction of the reference system was 0.46 . As it can be seen in Figure 8figure 8 , an increase in the PVT collector's area can cause a very steep increase in the solar electrical fraction, due to larger electrical production. It can be observed that buffer tanks smaller than 200 liters decreased the solar electrical fraction of the system. The reason is as described before that, an electrical heater was used during some periods in the winter where the buffer tank temperature reached temperatures below $-7{ }^{\circ} \mathrm{C}$. This led to higher electricity consumption and thus lower solar electrical fraction. On the contrary, a smaller DHW tank increased marginally the solar electrical fraction due to less operation of the heat pump in order to charge the tank.

From Figure 7Figure 7 and Figure 8Figure 8 , it can be observed that a larger collector area is always beneficial regarding electricity production while there is a limit in how much thermal energy from the PVT collector can be utilized by the system. This suggests that, from a certain collector area and on, it might be more beneficial to install PV panels instead of increasing the PVT area.

Figure 9 Figure 9 shows the net renewable energy fraction for the system including the parameter 


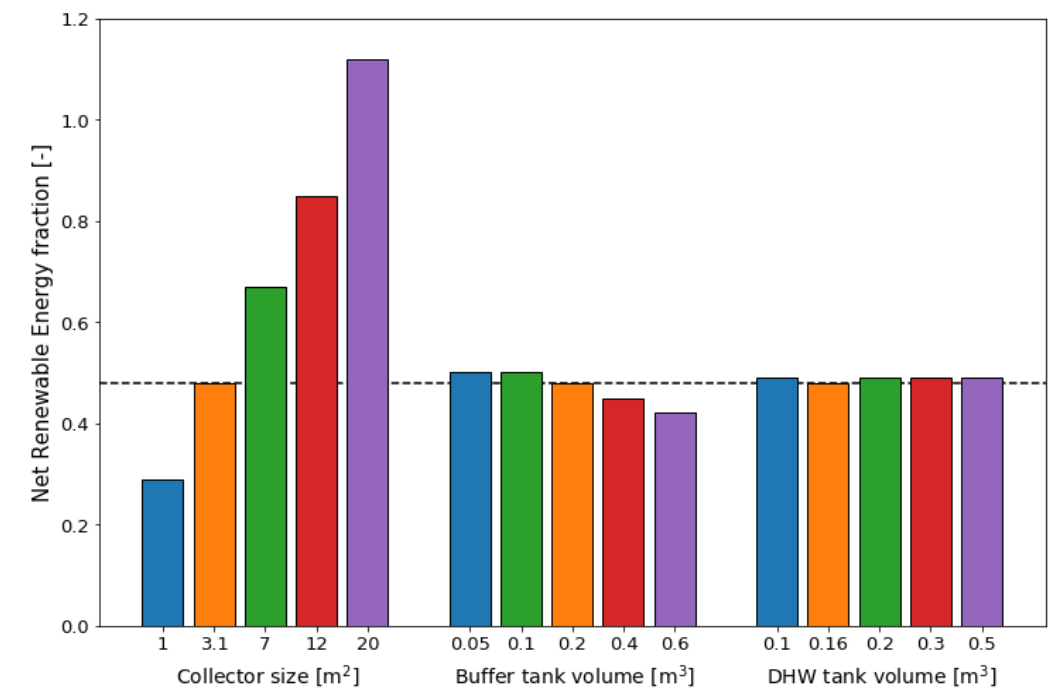

Figure 9: Net renewable energy fraction for collector size, buffer and DHW tank volume parametric analysis.

The net renewable energy fraction of the reference system was 0.48 . In Figure 9figure 9 , it can be observed that an increase in the PVT collector area increases the renewable energy fraction dramatically, since the system produces more thermal and electrical energy. A smaller buffer tank increases marginally the net renewable energy fraction, because it decreases the available energy amount to the heat pump source, making the fraction larger. The parameter variation on the DHW volume had almost no effect on this $\mathrm{KPI}$.

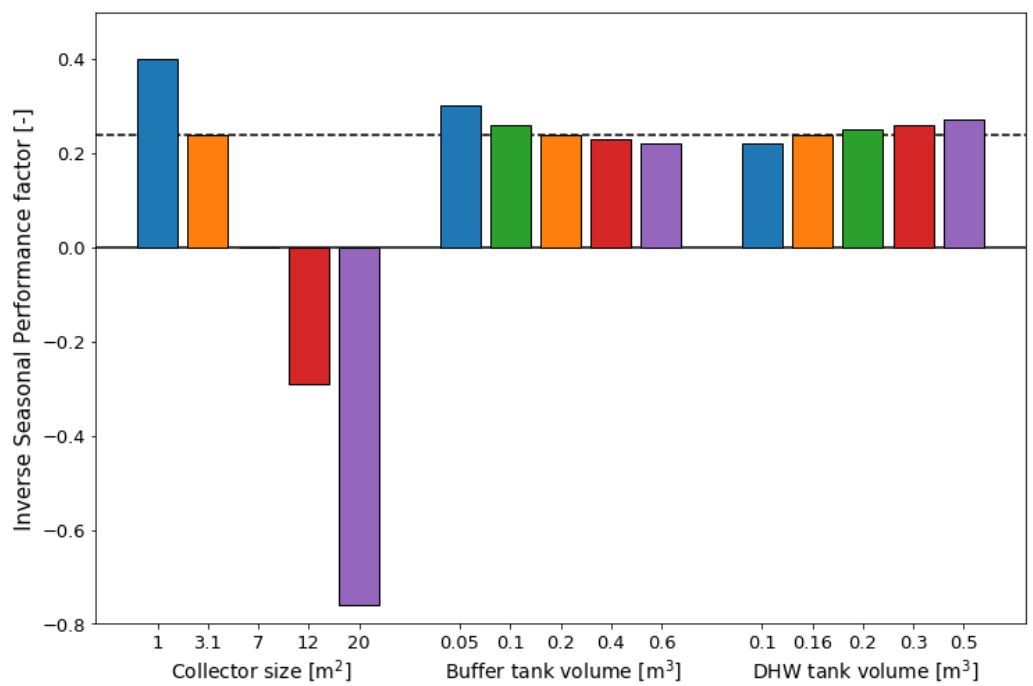

Figure 10: Inverse seasonal performance factor for collector size, buffer and DHW tank volume parametric analysis.

The inverse seasonal performance factor of the reference system was 0.24 . This indicator shows the amount of electricity the system uses per unit of provided heat (positive values) or the amount of electricity the system feds to the grid per unit of provided heat (negative values). So, contrary to the previously mentioned fractions, a lower value of this factor is considered more beneficial for the system performance. 
The only scenarios that produce more electricity than needed are the cases with the collector areas larger than $7 \mathrm{~m}^{2}$. It can be observed that the small buffer tanks, which use the electrical heater in the winter, have a worse performance factor than the larger tanks. On the contrary, smaller DHW tanks performed better due to less operation of the heat pump and thus less electricity consumption.

\subsubsection{System improvements}

Apart from the parameter variation of the system components, some improvement scenarios were investigated for the reference system regarding insulation, pipe length and heat exchanger height. The pipe length between the heat pump and the tanks in the reference system were $4 \times 6 \mathrm{~m}$ and in the TRNSYS model, another $21 \mathrm{~m}$ were added for including the thermal mass of the heat pump. In addition, the DHW tank top heat losses were $0.8 \mathrm{~W} /{ }^{\circ} \mathrm{C}$ and the $\mathrm{DHW}$ tank heat exchanger height equal to $0.6 \mathrm{~m}$.

The physical placement of the components in the demonstration system was not optimal, leading to long pipe loops between the heat pump and the storage tanks. A possible improvement scenario was a decrease of pipe length between the tanks and the heat pump by placing them closer together. Also, the DHW tank had two pipes exiting the top of the tank, creating thermal bridges and losses from the top of the tank. An improved scenario for this case could either be a better insulated top of the DHW tank or a different tank where there would be no pipes exiting the top. Lastly, the heat exchanger of the DHW tank connected to the heat pump, was able to charge only the upper part of the tank. Since the heat pump operation was short, it was considered interesting to investigate a scenario where the heat exchanger was reaching the bottom of the tank, so that the heat pump was able to charge the entire tank. For these reasons, three scenarios were investigated; namely one with reducing the $4 \times 6 \mathrm{~m}$ pipes to $4 \times 1 \mathrm{~m}$ (keeping the $21 \mathrm{~m}$ for the heat pump thermal mass), one with the DHW tank top heat losses of $0.2 \mathrm{~W} /{ }^{\circ} \mathrm{C}$ and one with the height of the upper DHW tank heat exchanger of $1.2 \mathrm{~m}$. The results are presented in Table 5 Fable 5.

Table 5: KPIs for pipe length, DHW top heat loss and DHW tank heat exchanger height variations.

\begin{tabular}{ccccc}
\hline & $\begin{array}{c}\text { Solar thermal } \\
\text { fraction }\end{array}$ & $\begin{array}{c}\text { Solar electrical } \\
\text { fraction }\end{array}$ & $\begin{array}{c}\text { Net Renewable } \\
\text { Energy fraction }\end{array}$ & ISPF \\
\hline Reference system & 0.49 & 0.46 & 0.48 & 0.24 \\
$\begin{array}{c}\text { Total pipe length of } 4 \mathrm{~m} \\
\mathrm{DHW} \text { tank top heat loss of } 0.2\end{array}$ & 0.51 & 0.54 & 0.51 & 0.19 \\
$\mathrm{~W} /{ }^{\circ} \mathrm{C}$ & 0.49 & 0.50 & 0.49 & 0.20 \\
Heat Exchanger height of $1.2 \mathrm{~m}$ & 0.50 & 0.48 & 0.48 & 0.24 \\
\hline
\end{tabular}

It can be observed that shorter pipe length improved all KPIs for the system, indicating that the pipe losses are high. By increasing the DHW tank top insulation, only the solar electrical fraction and ISPF were improved significantly, indicating that the electrical performance of the system is improved having the same thermal performance. This can lead to the conclusion that the tank losses from the DHW tank were high. By better insulating the DHW tank, the heat pump operation for charging the tank would be decreased (leading to lower electricity consumption), thus improving the electrical performance of the system. Lastly, a larger heat exchanger in the DHW tank that could charge the entire tank seems to increase marginally the performance of the system, probably due to more optimal operation of the heat pump.

\subsubsection{System performance}


In general it could be stated that the component that affected the performance of the system the most, based on the studied KPIs, was the PVT collector area. A $7 \mathrm{~m}^{2}$ was selected for the improved system since for larger collector areas the heat produced were only to a small extend utilized by the system.

It was decided to use the existing buffer tank for the improved system. The reason was that, although a smaller buffer tank increased the thermal fraction by $8 \%$ and the renewable fraction by $4 \%$, at the same time it decreased the electrical fraction by $7 \%$ and the system performance factor by $25 \%$. On the contrary, a smaller DHW tank seemed to perform equally well, thus it was decided to use a smaller one. Although in this study, the cost of the components was not included in the calculations, the choice of component sizes for the improved system was done having in mind that smaller component sizes have also lower costs.

For this reason, the decided optimized system consisted of a $7 \mathrm{~m}^{2}$ PVT collector, $0.2 \mathrm{~m}^{3}$ buffer tank, $0.1 \mathrm{~m}^{3} \mathrm{DHW}$ tank, DHW top heat loss of $0.2 \mathrm{~W} /{ }^{\circ} \mathrm{C}$, a pipe lengths between heat pump and tanks of 4 $\mathrm{x} 1 \mathrm{~m}$ and a DHW tank heat exchanger height of $1.2 \mathrm{~m}$. The results of the optimized system compared to the reference system are presented in Table 6 Fable 6 and Table 7 Fable 7.

\begin{tabular}{|c|c|c|c|c|c|c|}
\hline & $\begin{array}{l}\text { Heat to } \\
\text { DHW from } \\
\text { PVT [kWh] }\end{array}$ & $\begin{array}{l}\text { Heat } \\
\text { output } \\
\text { PVT } \\
\text { [kWh] }\end{array}$ & $\begin{array}{c}\text { Electrical } \\
\text { output } \\
\text { from PVT } \\
\text { [kWh] }\end{array}$ & $\begin{array}{l}\text { Heat pump } \\
\text { electric } \\
\text { consumption } \\
{[\mathrm{kWh}]}\end{array}$ & $\begin{array}{c}\text { Heat to } \\
\text { DHW from } \\
\text { heat pump } \\
{[\mathrm{kWh}]}\end{array}$ & $\begin{array}{c}\text { Heat } \\
\text { extracted } \\
\text { from buffer } \\
\text { tank by heat } \\
\text { pump [kWh] }\end{array}$ \\
\hline $\begin{array}{c}\text { Reference } \\
\text { system }\end{array}$ & 135 & 1089 & 296 & 699 & 1748 & 1979 \\
\hline $\begin{array}{l}\text { Improved } \\
\text { system }\end{array}$ & 165 & 1093 & 661 & 518 & 1555 & 1549 \\
\hline
\end{tabular}

The optimized system PVT collector area was 56\% larger than the reference system's. That led to $55 \%$ higher electricity production by the PVT collector. However, it can be observed that the heat output from the two collectors was very similar, indicating that the larger collector operated less time, as there were longer periods where the heat produced by the collector cannot be utilized by the system. Also, even in the optimized system, the amount of heat that was transferred directly from the PVT collector to the DHW tank was quite small on a yearly basis. This can be explained by the unglazed PVT collector can produce water temperatures around $30{ }^{\circ} \mathrm{C}$, while the temperature in the top of the DHW tank should be at $50{ }^{\circ} \mathrm{C}$. This temperature difference makes the direct charge of the DHW tank limited even in the optimized scenario.

Due to lower system losses and higher source temperatures, the heat pump operation was improved in the optimized system leading to $23 \%$ lower electric consumption. Also, $11 \%$ less heat was necessary to be transferred to the DHW tank by the heat pump, since the heat from the PVT collector had been utilized more and the DHW tank and pipes had lower heat losses.

In general, all the investigated KPIs were improved for the optimized system. On a yearly basis, the optimized system fed electricity to the grid for every unit of heat provided, unlike the reference system. 
Table 7: KPIs for reference and improved system.

\begin{tabular}{ccccc}
\hline & $\begin{array}{c}\text { Solar Thermal } \\
\text { fraction }\end{array}$ & $\begin{array}{c}\text { Solar Electrical } \\
\text { fraction }\end{array}$ & $\begin{array}{c}\text { Net Renewable } \\
\text { Energy fraction }\end{array}$ & $\begin{array}{c}\text { Inverse Seasonal } \\
\text { Performance Factor }\end{array}$ \\
\hline $\begin{array}{c}\text { Reference } \\
\text { system } \\
\text { Improved } \\
\text { system }\end{array}$ & 0.49 & 0.46 & 0.48 & 0.24 \\
\hline
\end{tabular}

It was noticed that even in the case of the improved system, a large amount of heat could not be utilized for various reasons (e.g. the temperature of the buffer and DHW tank was high during periods of sunshine thus no tank could be charged). That could potentially be solved by adding another tank for space heating purposes.

In the present study, no economic KPIs were calculated. The reason is that, since this system was only used for producing DHW, it was not financially attractive due to its high cost for covering such a low hot water demand. For this reason, it is firmly believed that the investigated system should be used also for space heating purposes if it is to become financially attractive. However, it has to be stated that the component sizes selected for the optimized system are likely to be different if the system is also used for providing space heating.

\subsection{Perspective}

The investigations showed that the principle of using a buffer storage tank, which was charged via a PVT collector, as the source for a liquid-to-liquid heat pump can work. This potentially allows for having heating systems with high performance without having the need for installing a ground sourced heat exchanger which may be more costly and space consuming to install. The correct sizing of the components related to the required load for the system is essential. The investigations in this study showed that with only a DHW load the system was oversized. Therefore it is suggested that for future investigations the focus should be on systems with larger loads, potentially combined DHW and space heating or for multifamily houses. The developed model can be a basis for future investigations of system with better system size with respect to load.

Under sizing the storage tank at the source side of the heat pump may lead to undesired low temperatures for the source for the heat pump, which may cause the heat pump to go into safety mode and use electricity directly for heating. With a proper sized system, the concept may allow for having performances better that air-to-liquid heat pump systems at a lower cost than systems with heat pumps and ground sourced heat exchanger. Compared to SAHP systems with the solar collector directly as the source for the heat pumps, the system with the buffer tank does allow for higher inlet temperatures for the source side of the heat pump which can increase the heat pump performance. This may be during a cold night after a sunny day where heat extracted by solar collectors can be stored in the buffer tank until the night. Further, the study showed that the uninsulated PVT collector could be used to charge the buffer storage tank in situations without any useful solar irradiance available e.g. after the heat pump had operated and the buffer storage temperature dropped below the ambient air temperature. 


\section{Conclusions}

A novel heating system consisting of heat pump, PVT collector, buffer tank and DHW tank for supplying a single family house in Denmark with domestic hot water was investigated. Experimental investigations of the system occurred from August to December 2017 at the test facilities of the Technical University of Denmark (DTU). The measurement period was used for validating a TRNSYS model of the system, which was later used for performing a yearly simulation of the system with Danish reference conditions. Key Performance Indicators (KPIs) were calculated in order to evaluate the system's thermal and electrical performance. A parameter variation of the sizes of the system's components (PVT collector area, buffer and DHW tank volume) was performed in order to identify a combination for higher performance. The key findings of the study were:

- For a system that produces only DHW, the thermal performance of the system increased when the size of the buffer and the DHW tank were the smallest investigated; namely 0.05 and $0.1 \mathrm{~m}^{3}$ respectively. This indicated that the system under investigation was probably over-dimensioned and should be further investigated for providing space heating as well.

- A larger heat exchanger in the DHW tank that can charge the entire tank volume can benefit the system regarding performance due to more optimal operation of the heat pump.

- The suggested improved system produced $55 \%$ more electricity, had $23 \%$ lower electric consumption and wasted $11 \%$ less heat by minimizing heat losses. It consisted of a $7 \mathrm{~m}^{2}$ PVT collector, $0.2 \mathrm{~m}^{3}$ buffer tank, $0.1 \mathrm{~m}^{3} \mathrm{DHW}$ tank, DHW top heat loss of $0.2 \mathrm{~W} /{ }^{\circ} \mathrm{C}$, pipe lengths of $4 \times 1 \mathrm{~m}$ between the heat pump and tanks and a heat exchanger height of $1.2 \mathrm{~m}$.

The investigations have shown that the principle of having a buffer storage tank, which can be charged by an uncovered PVT collector, as the source of the heat pump works. Every time the heat pump ran and discharged the buffer tank, it was recharged by the PVT collectors to the temperature level of the ambient air even in situations without solar irradiance available. The results indicate that the performance of a system can be dramatically improved by choosing appropriate-sized components. However, the optimal size of the components depends on the use of the system and thus it can be challenging to be identified before the realization of the system. Further, for a system with this complexity, the load needs to be larger than what was presented in this study in order to make the system economically attractive.

\section{Acknowledgement}

The research was financed by the Danish Energy Agency through EUDP grant no. 64017-05157 and Bjarne Saxhofs Fond.

\section{References}

[1] The European Commission, "Heating and cooling - European Commission," 2018. [Online]. Available: https://ec.europa.eu/energy/en/topics/energy-efficiency/heating-and-cooling. [Accessed: 08-Oct-2018].

[2] Z. Tian et al., "Large-scale solar district heating plants in Danish smart thermal grid: Developments and recent trends," Energy Conversion and Management, vol. 189. pp. 67-80, 
Jun-2019.

[3] M. D’Antoni, R. Fedrizzi, and W. Sparber, "IEA - SHC Task 44 / HPP Annex 38 Solar and Heat Pump Systems - Industry Newsletter - Second issue," 2012.

[4] “IEA SHC || Task 60 || IEA SHC || Task 60." [Online]. Available: http://task60.iea-shc.org/. [Accessed: 19-Oct-2019].

[5] E. Bellos, C. Tzivanidis, K. Moschos, and K. A. Antonopoulos, "Energetic and financial evaluation of solar assisted heat pump space heating systems," Energy Convers. Manag., vol. 120, pp. 306-319, 2016.

[6] F. M. Rad, A. S. Fung, and W. H. Leong, "Feasibility of combined solar thermal and ground source heat pump systems in cold climate, Canada," Energy Build., vol. 61, pp. 224-232, 2013.

[7] A. Buonomano, F. Calise, A. Palombo, and M. Vicidomini, "BIPVT systems for residential applications: An energy and economic analysis for European climates," Appl. Energy, vol. 184, pp. 1411-1431, 2016.

[8] J. P. Fine, J. Friedman, and S. B. Dworkin, "Detailed modeling of a novel photovoltaic thermal cascade heat pump domestic water heating system," Renew. Energy, vol. 101, pp. 500-513, 2017.

[9] F. Busato, R. Lazzarin, and M. Noro, "Ground or solar source heat pump systems for space heating: Which is better? Energetic assessment based on a case history," Energy Build., vol. 102, pp. 347-356, 2015.

[10] M. Lämmle, A. Oliva, M. Hermann, K. Kramer, and W. Kramer, "PVT collector technologies in solar thermal systems: A systematic assessment of electrical and thermal yields with the novel characteristic temperature approach," Sol. Energy, vol. 155, pp. 867-879, 2017.

[11] A. Zarrella, G. Emmi, J. Vivian, L. Croci, and G. Besagni, "The validation of a novel lumped parameter model for photovoltaic thermal hybrid solar collectors: a new TRNSYS type," Energy Convers. Manag., vol. 188, pp. 414-428, May 2019.

[12] F. Calise, M. Dentice D'accadia, D. Figaj, and L. Vanoli, “Thermoeconomic optimization of a solar-assisted heat pump based on transient simulations and computer Design of Experiments," 2016.

[13] G. Emmi, A. Zarrella, and M. De Carli, "A heat pump coupled with photovoltaic thermal hybrid solar collectors: A case study of a multi-source energy system," Energy Convers. Manag., vol. 151, pp. 386-399, Nov. 2017.

[14] H. Jouhara et al., "The performance of a heat pipe based solar PV/T roof collector and its potential contribution in district heating applications," Energy, vol. 136, pp. 117-125, Oct. 2017.

[15] P. Dupeyrat, C. Ménézo, and S. Fortuin, "Study of the thermal and electrical performances of PVT solar hot water system," Energy Build., vol. 68, pp. 751-755, Jan. 2014.

[16] D. Gürlich, A. Dalibard, and U. Eicker, "Photovoltaic-thermal hybrid collector performance for direct trigeneration in a European building retrofit case study," Energy Build., vol. 152, pp. 701-717, Oct. 2017.

[17] J. F. Chen, L. Zhang, and Y. J. Dai, "Performance analysis and multi-objective optimization of a hybrid photovoltaic/thermal collector for domestic hot water application," Energy, vol. 143, pp. 500-516, Jan. 2018. 
[18] Y. W. Li, R. Z. Wang, J. Y. Wu, and Y. X. Xu, "Experimental performance analysis on a directexpansion solar-assisted heat pump water heater," Appl. Therm. Eng., vol. 27, no. 17-18, pp. 2858-2868, Dec. 2007.

[19] J. Deng, Z. Tian, J. Fan, M. Yang, S. Furbo, and Z. Wang, "Simulation and optimization study on a solar space heating system combined with a low temperature ASHP for single family rural residential houses in Beijing," Energy Build., vol. 126, pp. 2-13, 2016.

[20] E. I. Sakellariou, A. J. Wright, P. Axaopoulos, and M. A. Oyinlola, "PVT based solar assisted ground source heat pump system: Modelling approach and sensitivity analyses," Sol. Energy, vol. 193, pp. 37-50, Nov. 2019.

[21] M. Aldubyan and A. Chiasson, "Thermal Study of Hybrid Photovoltaic-Thermal (PVT) Solar Collectors Combined with Borehole Thermal Energy Storage Systems," Energy Procedia, vol. 141, pp. 102-108, Dec. 2017.

[22] D. Jonas, G. Frey, and D. Theis, "Simulation and performance analysis of combined parallel solar thermal and ground or air source heat pump systems," Sol. Energy, vol. 150, pp. 500511, 2017.

[23] H. Li, L. Sun, and Y. Zhang, "Performance investigation of a combined solar thermal heat pump heating system," Appl. Therm. Eng., vol. 71, no. 1, pp. 460-468, 2014.

[24] C. Xi, L. Lin, and Y. Hongxing, "Long term operation of a solar assisted ground coupled heat pump system for space heating and domestic hot water," Energy Build., vol. 43, no. 8, pp. 1835-1844, 2011.

[25] X. Chen and H. Yang, "Performance analysis of a proposed solar assisted ground coupled heat pump system," Appl. Energy, vol. 97, pp. 888-896, 2012.

[26] S. Poppi, C. Bales, M. Y. Haller, and A. Heinz, "Influence of boundary conditions and component size on electricity demand in solar thermal and heat pump combisystems," Appl. Energy, vol. 162, pp. 1062-1073, 2016.

[27] S. Poppi et al., "Analysis of system improvements in solar thermal and air source heat pump combisystems," Appl. Energy, vol. 173, pp. 606-623, 2016.

[28] S. J. Sterling and M. R. Collins, "Feasibility analysis of an indirect heat pump assisted solar domestic hot water system," Appl. Energy, vol. 93, pp. 11-17, 2012.

[29] C. Tzivanidis, E. Bellos, G. Mitsopoulos, K. A. Antonopoulos, and A. Delis, "Energetic and financial evaluation of a solar assisted heat pump heating system with other usual heating systems in Athens," Appl. Therm. Eng., vol. 106, pp. 87-97, 2016.

[30] A. Girard, E. J. Gago, T. Muneer, and G. Caceres, "Higher ground source heat pump COP in a residential building through the use of solar thermal collectors," Renew. Energy, vol. 80, pp. 26-39, 2015.

[31] E. Kjellsson, G. Hellström, and B. Perers, "Optimization of systems with the combination of ground-source heat pump and solar collectors in dwellings," Energy, vol. 35, no. 6, pp. 26672673, 2010.

[32] P. Pärisch, O. Mercker, J. Warmuth, R. Tepe, E. Bertram, and G. Rockendorf, "Investigations and model validation of a ground-coupled heat pump for the combination with solar collectors," Appl. Therm. Eng., vol. 62, no. 2, pp. 375-381, 2014.

[33] S. H. Razavi, R. Ahmadi, and A. Zahedi, "Modeling, simulation and dynamic control of solar assisted ground source heat pump to provide heating load and DHW," Appl. Therm. Eng., vol. 
129, pp. 127-144, 2018.

[34] F. Reda, N. Arcuri, P. Loiacono, and D. Mazzeo, "Energy assessment of solar technologies coupled with a ground source heat pump system for residential energy supply in Southern European climates," Energy, vol. 91, pp. 294-305, 2015.

[35] Q. Si, M. Okumiya, and X. Zhang, "Performance evaluation and optimization of a novel solarground source heat pump system," Energy Build., vol. 70, pp. 237-245, 2014.

[36] E. Wang, A. S. Fung, C. Qi, and W. H. Leong, "Performance prediction of a hybrid solar ground-source heat pump system," Energy Build., vol. 47, pp. 600-611, 2012.

[37] M. Dannemand, B. Perers, and S. Furbo, "Performance of a demonstration solar PVT assisted heat pump system with cold buffer storage and domestic hot water storage tanks," Energy Build., vol. 188-189, pp. 46-57, Apr. 2019.

[38] Department of Civil Engineering; Technical University of Denmark, "DTU Climate Station." .

[39] M. Stegmann, E. Bertram, G. Rockendorf, and S. Janßen, "Model of an unglazed photovoltaic thermal collector based on standard test procedures," Proc. ISES Sol. World Congr. 2011, pp. 252-260, 2011. 


\section{Author Contribution Statement:}

Mark Dannemand and Zhiyong Tian: Conceptualization, Methodology, Software. Mark Dannemand, loannis Sifnaios, and Zhiyong Tian: Data curation, Writing- Original draft preparation. Dannemand and Ioannis Sifnaios: Visualization, Investigation, Validation. Simon Furbo: Supervision. Mark

Dannemand, loannis Sifnaios, Zhiyong Tian, and Simon Furbo: Writing- Reviewing and Editing. 


\section{Declaration of interests}

$\bigotimes$ The authors declare that they have no known competing financial interests or personal relationships that could have appeared to influence the work reported in this paper.

$\square$ The authors declare the following financial interests/personal relationships which may be considered as potential competing interests:

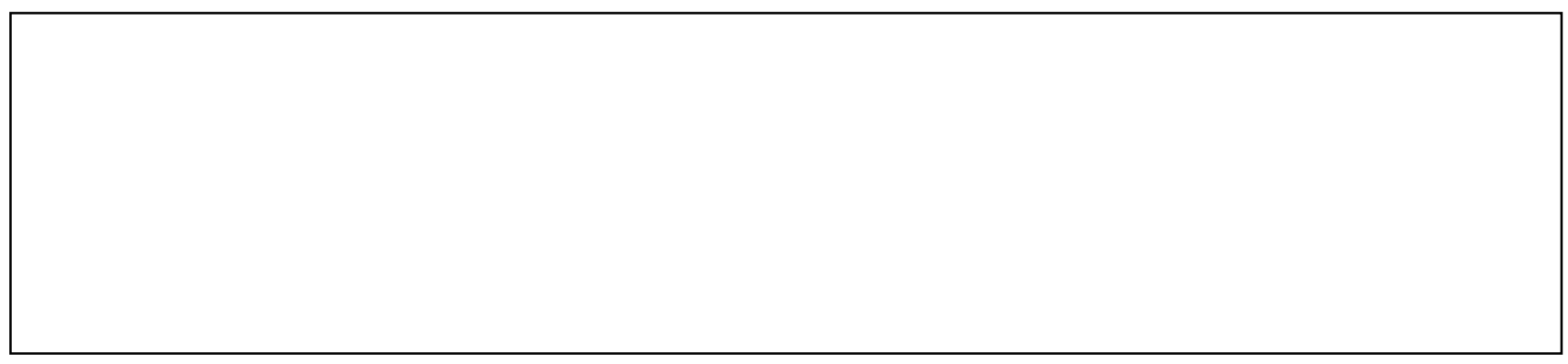

